\title{
Evaluation of ecological risk, source and spatial distribution of some heavy metals in marine sediments in the Middle and Eastern Black Sea region, Turkey
}

\section{Aylin Apaydın}

Republic of Turkey Ministry of National Education: Turkiye Cumhuriyeti Milli Egitim Bakanligi

Hatice Kabaoğlu

Gazi University: Gazi Universitesi

Gökhan Apaydın ( $\sim$ gapaydin@ktu.edu.tr)

Karadeniz Technical University: Karadeniz Teknik Universitesi

\section{Murat Şirin}

Recep Tayyip Erdo?an Üniversitesi - Milli Piyango Egitim Kampusu: Recep Tayyip Erdogan Universitesi

\section{Erhan Cengiz}

Alanya Alaaddin Keykubat Üniversitesi: Alanya Alaaddin Keykubat Universitesi

\section{Oğuz Kağan Köksal}

Adıyaman Üniversitesi: Adiyaman Universitesi

\section{Hasan Baltaş}

Recep Tayyip Erdoğan University: Recep Tayyip Erdogan Universitesi

\section{Engin Tıraşoğlu}

Karadeniz Technical University: Karadeniz Teknik Universitesi

\section{Research Article}

Keywords: Middle and Eastern Black Sea, Sediment, EDXRF, Pollution indices, Ecologic risk

Posted Date: April 6th, 2021

DOl: https://doi.org/10.21203/rs.3.rs-320256/v1

License: (a) This work is licensed under a Creative Commons Attribution 4.0 International License. Read Full License

Version of Record: A version of this preprint was published at Environmental Science and Pollution Research on August 31st, 2021. See the published version at https://doi.org/10.1007/s11356-021-16017- 
1 Evaluation of ecological risk, source and spatial distribution of some heavy

2 metals in marine sediments in the Middle and Eastern Black Sea region,

Aylin Apaydın" ${ }^{1}$ Hatice Kabaoğlu² ${ }^{2}$ Gökhan Apaydın ${ }^{3 *}$ Murat Şirin ${ }^{4}$, Erhan Cengiz ${ }^{5}$.

${ }^{1}$ Ministry of National Education, Trabzon, Turkey

*Corresponding Author: gapaydin@ktu.edu.tr

Orcid Number: 0000-0002-4647-344X 


\section{Abstract}

In the present study, the concentration levels of heavy metals such as $\mathrm{Mn}, \mathrm{Fe}, \mathrm{Ni}, \mathrm{Cu}, \mathrm{Zn}, \mathrm{Cr}$ and $\mathrm{Pb}$ in sediment samples collected from 16 sampling locations in the Middle and Eastern Black Sea regions, Turkey was measured using energy dispersive $\mathrm{X}$-ray fluorescence spectroscopy (EDXRF). Various pollution parameters and methods, such as the enrichment factor $(\mathrm{EF})$, geo-accumulation index (Igeo), contamination factor $(\mathrm{CF})$, pollution load index (PLI), ecological risk index (RI), and geo-spatial distribution patterns were used to assess in detail the pollution status, ecological risks and sources of metals in sediment. The mean concentrations of $\mathrm{Mn}, \mathrm{Fe}, \mathrm{Ni}, \mathrm{Cu}, \mathrm{Zn}, \mathrm{Cr}$ and $\mathrm{Pb}$ were found to be 565.38, 46,000, 34.38, 104.06, 109.88, 87.31, and $32.31 \mathrm{mg} / \mathrm{kg}$, respectively. Results showed that the mean concentrations of $\mathrm{Cu}, \mathrm{Zn}$ and $\mathrm{Pb}$ exceeded the crustal shale value, with the exception of $\mathrm{Mn}$, $\mathrm{Fe}$, Ni and $\mathrm{Cr}$. According to the calculated pollution parameters, although minimal or moderate pollution was detected in the area investigated, it was determined that there was a very low ecological risk. Multivariate statistical analysis results showed that $\mathrm{Cu}, \mathrm{Zn}$, and $\mathrm{Pb}$ levels in the investigated region were slightly influenced by anthropogenic inputs such as mining and agricultural practices. In addition, the geo-spatial distributions of $\mathrm{Cu}, \mathrm{Zn}, \mathrm{Fe}$ and $\mathrm{Pb}$ were found to be higher in this region due to the mining activities carried out in the Eastern Black Sea region.

Keywords Middle and Easterm Black Sea· Sediment· EDXRF· Pollution indices Ecologic risk 


\section{Introduction}

Human activities and the processes of rocks such as fragmentation, transportation and sedimentation are increasing the accumulation of heavy metals in sea bottoms. The metals that are soluble in water collapse and accumulate in the sediment; especially the accumulation of heavy metals in the larger parts where rivers meet with lakes and seas with intersection is more intense. The concentration of heavy metals deposited in the sediment varies depending on the ratio of sediment particles at the bottom, the size of the particles, and the presence of organic matter in the sediment. Sediment is an important accumulation place for heavy metals. Therefore, it is very often used in the determination of metal contamination of the aquatic environment.

The Black Sea is a semi-closed basin and has the largest anoxic water basin (Akyüz et al. 2001; Alkan et al. 2015) and it is enclosed by Bulgaria, Georgia, Romania, Russia, Ukraine, and Turkey. Turkish Black Sea has a long coast and the region has developing population, industrialization and urbanization (Bakan and Büyükgüngör 2000; Ergül et al. 2008). Agricultural surface water and inadequate treatment of urban sewage effluents are the main sources of metal pollution in the Black Sea coast of Turkey (Topcuoglu et al. 2003). In addition, the Black Sea region has a very rich potential in terms of $\mathrm{Cu}, \mathrm{Zn}$ and $\mathrm{Pb}$ mineral reserves. For this reason, the wastes of the mentioned mines are transported to the marine environment by means of surface waters, as well as rivers and streams of various sizes (Çevik et al. 2008; Baltas et al. 2017a). Therefore, the sediments in the Black Sea have been negatively suffered by the anthropogenic contaminations (Yiğiterhan and Murray 2008; Mülayim and Balkıs 2015).

The contamination of the marine ecosystem is still an important ecological issue worldwide. There are two main reasons for the pollution associated with natural and anthropogenic sources. The main causes of natural pollution are erosion because of wave 
action and glaciers, ore-bearing rocks, metals released from sediments by a chemical process, windblown dust, forest fires, chemical leaching of bedrock, water drainage basins, runoff from banks, and vegetation in small amounts. The major reasons for the anthropogenic sources are mining operations, industrial waste disposal, burning of fossil fuels in motor vehicles, and the smelting and refining metals (Turekian 1971; Bryan 1976; FernandezLeborans and Herrero 2000; Järup 2003; Bat et al. 2015). Anthropogenic sources have great importance for the formation of the metal, particularly near coastal sediment (Alkan et al. 2015). Therefore, sediments in the marine ecosystem can provide information on the heavy metal pollutant for the aquatic system.

Heavy metal pollution has a significant role in the contamination of aquatic systems. It is well known that sediments are one of the main transporters of heavy metals to the marine ecosystem (Chatterjee et al. 2007; Idris 2008; Cukrov et al. 2011). Therefore, sediment has an important role in monitoring the heavy metal pollution in the marine environment (Wardas et al. 1996; Ozkan and Buyukisik 2012).

The various works have pointed out that heavy metal contamination particularly in the aquatic ecosystem arose for more than a decade on a global scale. There are a few publications on marine ecosystem pollution in the region of the Black Sea using several analysis methods (Akyüz et al. 2003; Görür et al. 2012; Sur et al. 2012; Alkan et al. 2015, 2020; Ozseker et al. 2016; Baltas et al. 2017c; Ozseker and Eruz 2017; Sar1 et al. 2018; Ustun Odabaş1 et al. 2018). To refrain from the contamination of the aquatic environment, the European Union countries have taken measurements for defining heavy metal pollution.

In previous studies, no detailed studies on pollution have been found for the coasts of Samsun, Ordu, Giresun, Trabzon, Rize and Artvin provinces in recent years. Since pollution is a continuum process, it is necessary to carry out this study based on the coast of the Middle 
and Eastern Black Sea provinces. The main interest of the current work is to evaluate sources and ecologic risk status of the heavy metal pollution for marine sediments in the Middle and Eastern Black Sea coastal region with various parameters such as enrichment factor (EF), the geo-accumulation index ( $\left.\mathrm{I}_{\text {geo}}\right)$, contamination factor $(\mathrm{CF})$, pollution load index (PLI), and ecological risk index (RI). Multivariate statistical techniques such as Pearson's correlation and principal component analysis (PCA) were applied to evaluate relationships between metals and to define the input sources of heavy metals in sediment samples, respectively. In addition, geo-spatial distribution patterns of metals in sediments were investigated in the studied area. The results obtained may be utilized as a reference for monitoring possible metal contamination in the future.

(1)

(1)

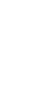

(1)

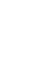

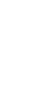

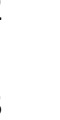

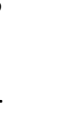

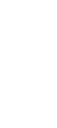

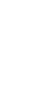

(1)

7




\section{Study area}

The Middle and Eastern Black sea regions include vast water valleys, mountain ranges, steppes and broken zones. Large water currents such as Yeşilırmak, Kızılırmak, İkizdere, Harşit, Batlama, Fırtına, Çoruh Rivers emerge from the sources of this region and pour into the Black Sea (Dalgic et al. 2018). This sampling points chosen for the study are located on the shores of this region and cover the Turkish provinces of Samsun, Ordu, Giresun, Trabzon, Rize, and Artvin (Fig. 1.). The detailed information related to the sampling points is given in Table S1 (Supplementary Materials).

\section{Sediment sampling and chemical analysis}

Marine sediment samples were gathered using a Van Veen grab sampler onboard the R / V speed research ship in August 2013 from 16 different sampling stations of the Middle and Eastern Black Sea coastal region of Turkey. The sediment samples were collected at different depths (10-30 depth) and different distances (0.2-2.0 sea miles). Three sediment samplings, approximately $1-2 \mathrm{~kg}$, were made at each sampling station. At the same time, the position of each sampling point was recorded by the automatic positioning system (GPS) on the research ship. At the points where the samples were taken, temperature and depth parameters were recorded automatically with the help of the CTD multi-parameter probe. The collected sediment samples were stored in clean polyethylene bags and immediately transferred to the laboratory in the cold chain box for further processing (Şirin 2019). Firstly, impurities such as plant fragments and stones were removed from sediment samples. After the sediment samples were weighed on a precision scale to be about $100 \mathrm{~g}$, they were left to dry at $105{ }^{\circ} \mathrm{C}$ for 48 hours until they reached a constant mass (Karbasdehi et al. 2016; Tholkappian et al. 2018) and the samples were ground to a fine powder in a mortar for 15-20 minutes. The samples were 
sieved with a $63 \mu \mathrm{m}$ sieve, as metals accumulated more as a result of the increase in surface area as the particles became smaller in size (Ravisankar et al. 2014; Kumar et al. 2017; Gholizadeh and Patimar 2018; Ni et al. 2018; Ustaoğlu and Islam 2020). Prior to metal analysis, the dried samples were placed in a vacuum evacuated desiccator. For measurements, after four grams of pretreated sediment powder and about 0.5 grams of Licowax powder were thoroughly mixed in a mortar to ensure homogeneity, it was pressed into a $40 \mathrm{~mm}$ diameter disc (pellet) by a 20 ton hydraulic press machine (Specac, Atlas TM Manual $25 \mathrm{~T}$ ). The contents of heavy metals such as $\mathrm{Mn}, \mathrm{Fe}, \mathrm{Ni}, \mathrm{Cu}, \mathrm{Zn}, \mathrm{As}$, and $\mathrm{Pb}$ in the sediment were determined using EDXRF spectrometer (Epsilon5, PANalytical, Almelo, the Netherlands). More detailed information about the used EDXRF spectrometer was given in the study by Baltas et al. (2020) (Baltas et al. 2020). Each pellet sample was analyzed in triplicate in the system (Baltas et al. 2017b). The measurement time was taken as 30 minutes for each pellet sample. As shown in Table S2, quality assurance and control of the method were achieved by using the national certified reference material, the Lake Ontario sediment (NW-WQB-1). The recovery of all metals analyzed in the reference material was between 95.4 and $104.7 \%$.

\section{Assessment of sediment pollution levels}

There are many methods to evaluate the size of heavy metal contamination in sediment samples in detail. Various parameters such as the enrichment factor (EF), geo-accumulation index (Igeo), contamination factor (CF), pollution load index (PLI), potential ecological risk factor $\left(\mathrm{E}_{\mathrm{r}}^{\mathrm{i}}\right)$, and potential ecological risk index (RI) were calculated to determine the level of heavy metals pollution and human input sources in marine sediment samples. Many researchers consider average shale or average crustal abundance values as reference (background) elements (Chandrasekaran et al. 2015; Baltas et al. 2020). For this reason, the values reported for the earth's shale by Krauskopf (1985) (Krauskopf 1985) were used as the reference (background) values for heavy metals and are given in Table 1. 


\section{Sediment Quality Guidelines (SQGs)}

172 It is very important to determine whether the concentration levels of heavy metals in 173 sediments pose an ecological risk to aquatic life. Therefore, risk assessment of heavy metals 174 in sediments was carried out by comparing the heavy metal concentrations with SQGs (Costa175 Böddeker et al. 2018; Fakhradini et al. 2019; Tian et al. 2020). According to the quality 176 directive, the indices are the threshold effect level (TEL) and the possible impact level (PEL).

177 Adverse effects rarely occur when metal concentration levels are below TEL, and often occur 178 when above PEL (Macdonald et al. 1996; Gao et al. 2019; Tian et al. 2020). To unify the

179

$193 \quad \mathrm{EF}=\frac{\left(\mathrm{C}_{\mathrm{n}} / \mathrm{C}_{\mathrm{Fe}}\right)_{\text {sample }}}{\left(\mathrm{B}_{\mathrm{n}} / \mathrm{B}_{\mathrm{Fe}}\right)_{\text {Background }}}$ examined are presented in Table 1.

\section{Enrichment factor (EF)}

192

standards, the potential risks posed by the measured metals were evaluated based on quality guidelines such as TEL and PEL values. TEL and PEL reference values of some of the metals

Generally, when the EF values are in the range of $0.5 \leq \mathrm{EF} \leq 1.5$, the metal enrichment is considered to be from natural weathering processes, ie lithogenic sources. If the EF value is greater than 1.5, it is stated that the main source of enrichment is anthropogenic inputs resulting from human activities (Tholkappian et al. 2018). The EF method reduces the influence of granularity and a mineralogical constituent of the investigated environmental medium on assessment results by normalizing heavy metal concentration to conservative element concentration ( $\mathrm{Lu}$ et al. 2009a, b). In the present work, Fe was taken as a reference because of its high concentration and stability in the earth's shale (Delgado et al. 2010; Varol and Şen 2012; Omwene et al. 2018; Baltas et al. 2020). The EF is calculated by the Eq. (1): 
$218 \quad \mathrm{CF}=\frac{\mathrm{C}_{\text {metal }}}{\mathrm{C}_{\text {background }}}$ where $\mathrm{C}_{\mathrm{n}}$ and $\mathrm{C}_{\mathrm{Fe}}$ are the concentration of the metal $\mathrm{n}$ and $\mathrm{Fe}$ in the sample, respectively. $\mathrm{B}_{\mathrm{n}}$ and $\mathrm{B}_{\mathrm{Fe}}$ are reference values given by Krauskopf (1985) for the metal $\mathrm{n}$ and $\mathrm{Fe}$, respectively (Krauskopf 1985). The pollution level of metals on base of the EF values is summarized in Table S3 (Chen et al. 2007).

\section{Geo-accumulation index (Igeo)}

Igeo, raised by Müller (1969) and extensively used to evaluate heavy metal pollution level in sediment, soil and dust (Muller 1969; Lu et al. 2017; Tholkappian et al. 2018; Xia et al. 2018), is calculated according to the Eq. (2):

$$
\mathrm{I}_{\text {geo }}=\log _{2}\left(\frac{\mathrm{C}_{\mathrm{n}}}{1.5 \times \mathrm{B}_{\mathrm{n}}}\right)
$$

where $C_{n}$ and $B_{n}$ are the concentration of metal $n$ in the sediment sample and its corresponding background value of earth's shale, respectively. Factor 1.5 is used to minimize the effect of possible changes in geogenic background values in sediment (Al-Haidarey et al. 2010). The pollution level of metals in terms of Igeo values is given in Table S3 (Kusin et al. 2018).

\section{Contamination factor (CF) and pollution load index (PLI)}

The pollution factor (CF) and pollution load index (PLI) were calculated to reveal the level of pollution in the sediments. The pollution factor is a good tool to estimate the pollution levels caused by metals in the environmental environment over a given time period (Ghani 2015). The CF can be calculated as follows depending on the Eq. (3) defined by Tomlinson et al. (1980) (Tomlinson et al. 1980): 
where $\mathrm{C}_{\text {metal }}$ and $\mathrm{C}_{\text {background }}$ are the content of metal $\mathrm{i}$ in the sediment and its background value

221

in earth's shale, respectively. According to the value of $\mathrm{CF}$, the $\mathrm{CF}$ was divided into four categories by Hakanson (1980) (Hakanson 1980) as given in Table S3.

PLI, defined as the geometric average of all individual pollution indexes of heavy metals determined in the sample (Tomlinson et al. 1980; Lu et al. 2014), can identify the comprehensive pollution level of heavy metals. It is calculated according to Eq. (4):

$$
\mathrm{PLI}=\sqrt[\mathrm{n}]{\mathrm{C}_{\mathrm{f} 1} \times \mathrm{C}_{\mathrm{f} 2} \times \mathrm{C}_{\mathrm{f} 3} \times \ldots \times \mathrm{C}_{\mathrm{fn}}}
$$

where $\mathrm{n}$ is the number of heavy metal elements analyzed. The PLI value less than 1 indicates uncontaminated sediment condition, whereas the PLI value greater than 1 indicates a contaminated sediment condition (Chakravarty and Patgiri 2009; Tholkappian et al. 2018; Baltas et al. 2020).

\section{Ecological risk evaluation of metals}

To identify the ecological risk of metals in the sediment, sediment quality guidelines (SQGs) and potential ecological risk index (RI) were applied in this study. RI, proposed by Hakanson (1980) (Hakanson 1980) and widely used in the ecological risk analysis of metals in sediment, soil and surface dust (Yi et al. 2011; Qin et al. 2014), is calculated according to Eq. (5)

$\mathrm{RI}=\sum_{\mathrm{i}} \mathrm{E}_{\mathrm{r}}^{\mathrm{i}}=\sum_{\mathrm{i}} \mathrm{T}_{\mathrm{r}}^{\mathrm{i} X \mathrm{C}_{\mathrm{f}}^{\mathrm{i}}}$

where $E_{r}^{i}$ is the potential ecological risk factor of each metal, $T_{r}^{i}$ is the toxic-response factor of metal i, which is 1 for $\mathrm{Mn}$ and $\mathrm{Zn}, 5$ for $\mathrm{Pb}, \mathrm{Ni}$ and $\mathrm{Cu}, 2$ for $\mathrm{Cr}$ (Hakanson 1980; Zhu et al. 2013; Zhang et al. 2014; Pejman et al. 2015), $\mathrm{C}_{\mathrm{f}}^{\mathrm{i}}$ is the contamination factor of metal i. The ecological risk grade on the base of the value of $\mathrm{E}_{\mathrm{r}}^{\mathrm{i}}$ and $\mathrm{RI}$ is displayed in Table S4. 
Descriptive statistics were used to analyze metals in the sediments of the Middle and Eastern

Black Sea. Kolmogorov Smirnov (K-S) test was applied to analyze whether the metal concentrations were normally distributed (Tian et al. 2017; Cai et al. 2019). Multivariate statistical methods such as correlation and principal component analysis (PCA) were used to judge possible sources of heavy metals. All statistical analyses for the data were performed by using IBM SPSS version 21.0 (SPSS Inc., USA) software. Moreover, spatial distribution maps of metals were visualized using ArcGIS version 10.1 to reveal hot spots of metal contamination. These methods utilized are widely used to investigate possible sources of pollutants in various environmental environments (Zhang et al. 2015; Zhu et al. 2016; Han 253 and Lu 2017; Zhuang and Lu 2020; Yu et al. 2021).

254

255

256

257

258

259

260

261 


\section{Heavy metal concentrations in sediment}

266

The descriptive statistics of measured metals in the sediment samples and average shale values reported by Krauskopf (1985) are listed in Table 1. The concentration of Mn, Fe, Ni, $\mathrm{Cu}, \mathrm{Zn}, \mathrm{Cr}$ and $\mathrm{Pb}$ varied between 326 and 820, 34,300 and 60,000, 8 and 171, 49 and 635, 54 and 456, 19 and 306 and 13 and $83 \mathrm{mg} / \mathrm{kg}$, respectively, with an average concentration of 565.38, 46,000, 34.38, 104.06, 109.88, 87.31, and $32.31 \mathrm{mg} / \mathrm{kg}$, respectively. Generally, average metal concentrations were found in the order of $\mathrm{Fe}>\mathrm{Mn}>\mathrm{Zn}>\mathrm{Cu}>\mathrm{Cr}>\mathrm{Ni}>\mathrm{Pb}$. In the ase of $\mathrm{Mn}, \mathrm{Fe}, \mathrm{Ni}$ and $\mathrm{Cr}$, the concentration in all sampling locations is lower than the average shale value reported by Krauskopf (1985) while the mean concentration of $\mathrm{Cu}, \mathrm{Zn}$, and $\mathrm{Pb}$ is greater than the average shale value due to pedogenic process and human-origin inputs such as mining activities, agricultural runoffs, and traffic emissions.

Since the metal concentrations in the investigated area showed a heterogeneous distribution, the standard deviation (SD) values were found to be high. In order to test the normality of the data, the Kolmogorov-Smirnov test $(\mathrm{K}-\mathrm{S})$ was applied to the data obtained and the distribution of the data was considered normal if the $p$ value was above 0.05 (Kelepertzis 2014; Cai et al. 2015). As a result of the K-S test, it was determined that all metals showed a normal distribution. Again, the skewness values were investigated to determine whether the distribution of metals was normal. If the skewness value is between -1 and 1 , the distribution of the metal is considered normal, and if it shows a slightly positive skewness value, it is considered abnormal (Chandrasekaran et al. 2015; Baltas et al. 2020). Hence, the concentrations of $\mathrm{Ni}, \mathrm{Cu}, \mathrm{Zn}$ and $\mathrm{Cr}$ were strongly skewed with the skewness higher than 1 , and the kurtosis was also higher than 1 , caused by the fact that the majority of samples were clustered at relatively low values ( $\mathrm{Lu}$ et al. 2010; Cai et al. 2019). It has indicated that the concentrations of $\mathrm{Ni}, \mathrm{Cu}, \mathrm{Zn}$ and $\mathrm{Cr}$ were not normally distributed. The 
skewness and kurtosis values of $\mathrm{Mn}$ and $\mathrm{Fe}$ metals less than 1 indicated that the concentrations of these metals have been normally distributed.

While the inputs of metals with low coefficient of variation (CV) are expressed by natural resources, the inputs of metals with high coefficient of variation (CV) are expressed mostly by human-induced activities.(Marcinkonis et al. 2011; Cai et al. 2015; Mamut et al. 2017; Baltas et al. 2020). Table 1 shows that the $\mathrm{CV}$ of $\mathrm{Ni}, \mathrm{Cu}, \mathrm{Zn}, \mathrm{Cr}$ was $127.37 \%$, $136.55 \%, 86.73 \%$, and $95.89 \%$, respectively, with high variation $(\mathrm{CV}>75 \%)$, and the $\mathrm{CV}$ of $\mathrm{Mn}$ and $\mathrm{Pb}$ was $25.79 \%$ and $59.64 \%$, respectively, with medium variation $(25 \%<\mathrm{CV}<$ $75 \%)$. The $\mathrm{CV}$ of Fe showed low variability $(\mathrm{CV}<25 \%)$. Therefore, the main input sources of $\mathrm{Mn}, \mathrm{Ni}, \mathrm{Cu}, \mathrm{Zn}, \mathrm{Cr}$ and $\mathrm{Pb}$ except $\mathrm{Fe}$ can be explained by anthropogenic activities. It can be said that the main source of Fe is the parent material or sediment topography (Mamut et al. 2017). Moreover, the results obtained reveal that there are significant variations in heavy metal concentrations and the spatial distribution of metals in the area under investigation is heterogeneous (Zhang et al. 2018).

The mean concentrations of heavy metals $(\mathrm{Mn}, \mathrm{Fe}, \mathrm{Ni}, \mathrm{Cu}, \mathrm{Zn}, \mathrm{Cr}$ and $\mathrm{Pb}$ ) in the sediments in the present research were compared with the mean values determined in similar studies, and the results are presented in Table 2. The mean concentrations of $\mathrm{Mn}$ and Fe in this study were determined to be lower than the mean values reported in Turkey (Çevik et al. 2008), but it was determined to be higher than the mean values reported in other researches. The mean concentrations of $\mathrm{Cu}, \mathrm{Zn}$ and $\mathrm{Pb}$ in this study were determined to be lower than the mean values reported in Turkey (Çevik et al., 2008; Alkan et al., 2020; Baltas et al., 2017c), but it was determined to be higher than the mean values reported in other researches. The mean value of $\mathrm{Ni}$ and $\mathrm{Cr}$ element was higher than all other studies in the literature. 
315 Compared with the SQGs, the average concentrations of $\mathrm{Cr}, \mathrm{Pb}, \mathrm{Cu}$, and $\mathrm{Ni}$ in the sediments exceeded the TEL values. These results show that the sediments occasionally showed potential ecological risks. $\mathrm{Zn}$ was below the TEL value, suggesting that the $\mathrm{Zn}$ in the sediment were not toxic (Table 1). In particular, the average concentrations of $\mathrm{Cr}, \mathrm{Pb}, \mathrm{Cu}, \mathrm{Ni}$ and $\mathrm{Zn}$ were found to be lower than the PEL values. Therefore, metal concentrations detected in sediment samples in the area under investigation do not tend to show adverse biological effects.

\section{Enrichment factor (EF)}

323

The calculated EF values for sediments are summarized and presented in Table 3. The average EF values of the metals were found in the order of $\mathrm{Cu}(1.98)>\mathrm{Pb}(1.77)>\mathrm{Zn}(1.23)$ $>\mathrm{Cr}(0.88)>\mathrm{Mn}(0.69)>\mathrm{Ni}(0.45)$. The mean EF values suggest no enrichment for $\mathrm{Cr}, \mathrm{Mn}$ and $\mathrm{Ni}$ unlike $\mathrm{Cu}, \mathrm{Pb}$, and $\mathrm{Zn}$ which indicates minimal enrichment. Average $\mathrm{EF}$ values were found to be less than 1.5 for $\mathrm{Mn}, \mathrm{Ni}, \mathrm{Cr}$ and $\mathrm{Zn}$, while it was higher than 1.5 for $\mathrm{Cu}$ and $\mathrm{Pb}$. Therefore, although the main sources of $\mathrm{Mn}, \mathrm{Ni}, \mathrm{Cr}$ and $\mathrm{Zn}$ are entirely from crustal materials or natural erosion processes, the main enrichment sources of $\mathrm{Cu}$ and $\mathrm{Pb}$ are anthropogenic inputs from industrial activities.

Geo-accumulation index (Igeo $)$

The calculated Igeo values for sediments are summarized and presented in Table 3. The average Igeo values of the heavy metals were found in the order of $\mathrm{Cu}(0.05)>\mathrm{Pb}(0.02)>\mathrm{Zn}$ $(-0.53)>\mathrm{Fe}(-0.63)>\mathrm{Mn}(-1.22)>\mathrm{Cr}(-1.28)>\mathrm{Ni}(-2.20)$. In general, the average Igeo values were found to be less than zero for all metals except $\mathrm{Cu}$ and $\mathrm{Pb}$. Based on the Müller classification, the geo-accumulation index shows that the Black Sea region is not 
contaminated with $\mathrm{Zn}, \mathrm{Fe}, \mathrm{Mn}$, As and $\mathrm{Ni}$, but uncontaminated to moderately polluted by $\mathrm{Cu}$ and $\mathrm{Pb}$.

\section{Contamination factor (CF) and pollution load index (PLI)}

The calculated CF and PLI values for metals are summarized and presented in Table 3. CF values decreased in the following descending order: $\mathrm{Cu}(2.08)>\mathrm{Pb}(1.62)>\mathrm{Zn}(1.22)>\mathrm{Fe}$ $(0.98)>\mathrm{Cr}(0.87)>\mathrm{Mn}(0.66)>\mathrm{Ni}(0.43)$. The average $\mathrm{CF}$ value for $\mathrm{Cu}, \mathrm{Pb}$, and $\mathrm{Zn}$ indicated the moderate contamination level, whereas the average $\mathrm{CF}$ value for $\mathrm{Fe}, \mathrm{Mn}, \mathrm{Ni}$ and Cr showed a very low pollution level. In addition, the average PLI value was found to be 0.73 . Since the average PLI is below 1, no contamination by the metals was detected in the area under investigation.

\section{Ecological risk evaluation}

Potential ecological risk index (RI) and ecological risk factor values calculated for heavy metals are given in Table 3. The average risk factors $\left(E_{r}^{i}\right)$ in sediment samples of the heavy metals were found in the order of $\mathrm{Cu}(10.41)>\mathrm{Pb}(8.08)>\mathrm{Ni}(2.15)>\mathrm{Cr}(1.75)>\mathrm{Zn}(1.22)$ $>\mathrm{Fe}(0.98)>\mathrm{Mn}(0.66)$. Since the average $\mathrm{E}_{\mathrm{r}}^{\mathrm{i}}$ values for all metals are lower than 40 , no ecological risk has been identified in the investigated area as a result of the toxicity factors of the metals. The average value of the RI in the area studied was found to be 31.61. Since the average RI value is lower than $\mathrm{RI}<50$, a very low ecological risk has been identified for all metals in the region. Moreover, Fig. 2 exhibited that $\mathrm{Cu}$ is the largest contributor $(42.87 \%)$ to RI, followed by $\mathrm{Pb}(33.28 \%), \mathrm{Ni}(8.86 \%), \mathrm{Cr}(7.21 \%), \mathrm{Zn}(5.02 \%)$ and $\mathrm{Mn}(2.76 \%)$. The contribution rates of metal(loid)s to RI are not only associated with their concentrations but also associated with their toxicity response factors. 


\section{Multivariate analysis of sediment heavy metals}

363

364

A matrix of Pearson's correlation coefficients was used to assess the degree of correlation among the metals and to distinguish the sources of the metals in the sediments (Table S5). The correlation analysis showed that there was a significantly positive relationship between the elemental pairs $\mathrm{Cu}-\mathrm{Zn}(r=0.973), \mathrm{Zn}-\mathrm{Cr}(r=0.960)$ and $\mathrm{Ni}-\mathrm{Cr}(r=0.845)$ at $p<0.01$. There was also a moderate positive relationship between $\mathrm{Fe}-\mathrm{Cu}(r=0.552)$, Ni-Distance $(r=$ $0.615)$ and $\mathrm{Cr}-$ Distance $(r=0.529)$ at $p<0.05$. According to the study published by Thollkappian et al. (2018), if the correlation coefficient between metals is positive, these metals may likely have a common source, interdependence, and the same behavior in the transportion process. Accordingly, common sources and transport of positively correlated metals may be similar (Wang et al. 2017). But, a moderate negative correlation exists between $\mathrm{Fe}$ and $\mathrm{Pb}(r=-0.574, p<0.05)$. Significant negative correlations between some heavy metals indicated that these heavy metals could be from different pollution sources (Chabukdhara and Nema 2013; Ahamad et al. 2020). Therefore, negatively correlated Fe and $\mathrm{Pb}$ can arise from different sources.

PCA analysis, one of the multivariate statistical methods, was also used to determine the relationships between metals in sediment and the sources of metals. Three main components with eigenvalues greater than 1 were identified, explaining $85.712 \%$ of the system variance. The graphical representation of the three components (PC 1, PC 2 and PC 3) where the relationships between heavy metals can be seen is given in Fig. 3. Liu et al. (2003) classified the factor loadings as strong $(<0.75)$, moderate $(0.75-0.50)$ and weak $(0.50-0.30)$ (Liu et al. 2003; Ustaoğlu and Islam 2020). As reported in Table 4, PC1 (38.503\% variance) showed strong positive loading for $\mathrm{Cu}, \mathrm{Zn}$ and moderate positive loading for Fe. In addition, we found a significant correlation between $\mathrm{Cu}-\mathrm{Zn}$ and $\mathrm{Fe}-\mathrm{Cu}$. The average $\mathrm{EF}$ values of $\mathrm{Cu}$ and $\mathrm{Zn}$ were obtained above 1 . Also, the mean concentrations of $\mathrm{Cu}$ and $\mathrm{Zn}$ in the sediments 
were more than the background concentrations. The minor enrichment for $\mathrm{Cu}$ and $\mathrm{Zn}$ in the study area may have resulted from low anthropogenic inputs, including domestic/municipal wastewaters and vehicle emissions (Sun et al. 2019). In addition, fertilizer and pesticide application in agriculture can be considered as the primary source of $\mathrm{Cu}$ and $\mathrm{Zn}$, due to the large amount of hazelnut and tea production in the study area (Chen et al. 2018; Song et al. 2019; Ustaoğlu and Islam 2020). Moreover, we can say that these metals are formed as a result of the mining activities operating intensively in the Eastern Black Sea region (Çevik et al. 2008; Baltas et al. 2017c). The average EF value of Fe was obtained below 1. The concentration of Fe was considered to result from natural sources (Zhu et al. 2013). Therefore, PC1 could be better explained as anthropogenic sources such as agricultural and mining (Kelepertzis 2014; Chandrasekaran et al. 2015; Ma et al. 2016; Baltas et al. 2017c; Lu et al. 2017; Zhu et al. 2019).

PC2 (31.515\% variance) showed a high factor loading on Ni and Cr. Additionally, there was a significant positive correlation between $\mathrm{Ni}$ and $\mathrm{Cr}$. The average $\mathrm{EF}$ values of $\mathrm{Ni}$ and $\mathrm{Cr}$ were obtained below 1 . The mean concentrations of $\mathrm{Ni}$ and $\mathrm{Cr}$ in the sediments were lower than the background concentrations. In previous studies, it was stated that the main sources of $\mathrm{Ni}$ and $\mathrm{Cr}$ in sediment are parent materials and pedogenic process (Wang et al. 2016; Cai et al. 2019). Therefore, the high loading factors detected for Ni and $\mathrm{Cr}$ in the PC2 component indicate that the levels of these metals can be attributed primarily to lithogenic effects (natural sources) (Jia et al. 2018; Xu et al. 2020).

PC3 (15.694\% variance) showed strong positive and negative loading for $\mathrm{Mn}$ and $\mathrm{Pb}$, respectively, while moderately positive loading for Fe. In addition, a weak positive correlation was found between $\mathrm{Mn}$ and $\mathrm{Fe}$, while a moderately negative correlation was found between $\mathrm{Fe}$ and $\mathrm{Pb}$. The average EF value of $\mathrm{Pb}$ was obtained above 1. Also, the mean concentration of $\mathrm{Pb}$ in the sediments was more than the background concentrations. The minor enrichment 
for $\mathrm{Pb}$ in the study area may have resulted from low anthropogenic inputs, including vehicle emissions and mine reserves (Çevik et al. 2008; Baltas et al. 2017c; Sun et al. 2019). The average $\mathrm{EF}$ values of $\mathrm{Mn}$ and Fe were obtained below 1. It is known that $\mathrm{Fe}$ and $\mathrm{Mn}$ metals are naturally occurring metals in the earth's crust. These metals come from natural resources such as coastal erosion and rock weathering (Savitha et al. 2018). The concentrations of Fe and $\mathrm{Mn}$ were considered to result from natural sources (Zhu et al. 2013). Therefore, PC3 could be better explained as the natural and anthropogenic sources such as agricultural and mining (Kelepertzis 2014; Chandrasekaran et al. 2015; Ma et al. 2016; Baltas et al. 2017c; Lu et al. 2017; Zhu et al. 2019).

\section{The spatial distribution of heavy metal contents of sediments}

The spatial distribution of heavy metal concentration in sediment samples collected from 16 different locations of the Eastern and Middle Black Sea is given in Fig. 4. The spatial distribution patterns of $\mathrm{Cu}, \mathrm{Fe}$, and $\mathrm{Zn}$ were quite similar. High levels of metals such as $\mathrm{Cu}$, Fe, and $\mathrm{Zn}$ were detected in Trabzon, Rize and Artvin provinces. While the lowest values of $\mathrm{Cu}$ and $\mathrm{Fe}$ were in Giresun, the lowest value of $\mathrm{Zn}$ was found in Samsun. The Eastern Black Sea region is also rich in mineral deposits. These include especially metals $\mathrm{Cu}, \mathrm{Zn}$ and $\mathrm{Pb}$ important to keep in one place and make an important contribution to Turkey's economy (Çevik et al. 2008; Baltas et al. 2017c). These mineral deposits were considered to be the main sources of high concentrations of $\mathrm{Cu}$ and $\mathrm{Zn}$ metals in the samples from the Eastern Black Sea region (Otansev et al. 2016; Baltas et al. 2017c; Ustaoğlu and Islam 2020). Moreover, the input sources of $\mathrm{Zn}$ into the marine environment are old ships (rust, old metal parts, paint on ship hulls), tourism activities, oil waste and sewage waste (Ali et al. 2016; Otansev et al. 2016). Besides, feed used for marine farming of animals was also reported to be a source of $\mathrm{Zn}$ and $\mathrm{Cu}$ elements (Tian et al. 2020). According to the PCA results, we believe 
that $\mathrm{Cu}$ and $\mathrm{Zn}$ can be controlled by human activities, while element Fe can be controlled by both lithogenic/geological sources (natural).

The spatial distribution of $\mathrm{Pb}$ concentrations was determined to be highest in Trabzon, Giresun, Ordu and Samsun provinces. The lowest values were found to be in the province of Artvin. The reason for the higher Pb levels in these sampling provinces can be explained by the fact that these regions have denser populations, mineral reserve deposits, and large port enterprises. In addition, traffic emissions, industrial, agricultural, domestic and humansourced wastes can be interpreted as the reason for the increase in $\mathrm{Pb}$ levels in marine sediments in this region (Filzek et al. 2004; Cai et al. 2012). According to the PCA results, it can be said that the input sources of $\mathrm{Pb}$ are anthropogenic.

When the spatial distributions for $\mathrm{Mn}, \mathrm{Cr}$ and $\mathrm{Ni}$ metals were examined, the highest concentrations were found in Samsun. It is thought that the reason for the high determination of these metals regionally is due to municipal wastewater discharges and unprocessed domestic wastes. In addition, the Mn element is used in the production of steel, batteries and chemicals (Otansev et al. 2016). Ni and $\mathrm{Cr}$ concentrations in sediments may be due to parent rock materials, geogenic origin or atmospheric deposition of vehicle emissions. In addition, the anthropogenic origin $\mathrm{Ni}$ inputs in sediments originate from various fertilizers used in agriculture (Cai et al. 2015; Ungureanu et al. 2017; Tian et al. 2020). Even so, we can say from the PCA results that high $\mathrm{Ni}, \mathrm{Cr}$ and $\mathrm{Mn}$ values are mainly affected by natural resources such as parent rock materials and coastal erosion. 


\section{Conclusions}

462 Heavy metals such as $\mathrm{Mn}, \mathrm{Fe}, \mathrm{Ni}, \mathrm{Cu}, \mathrm{Zn}, \mathrm{Cr}$ and $\mathrm{Pb}$ in sediment samples collected from 16 sampling locations in the Eastern and Middle Black Sea, Turkey were measured using EDXRF spectrometer. The results showed that Fe was the most abundant metal in all samples due to the abundance of iron in the earth's crust. The average concentrations of $\mathrm{Mn}, \mathrm{Fe}, \mathrm{Ni}$ and $\mathrm{Cr}$ were found to be lower than the crustal shale value, while the average concentrations of $\mathrm{Cu}, \mathrm{Zn}$ and $\mathrm{Pb}$ were higher due to natural rock erosion as well as anthropogenic inputs such as mineral deposits, agricultural activities, and traffic emissions. Pollution parameters such as EF, Igeo, CF and PLI were used to reveal the sources and risk status of metal contamination in the sediment in the studied marine region. According to these parameters, the sediment shows a minimal to moderate contamination of pollution of $\mathrm{Cu}, \mathrm{Zn}$ and $\mathrm{Pb}$. Since the average pollution load index (PLI) is less than one, no contamination by metals was detected in the area under investigation. According to the determined potential ecological risk index (RI) and ecological risk factor $\left(\mathrm{E}_{\mathrm{r}}^{\mathrm{i}}\right)$ values, it was revealed that there is a very low risk in the researched area. As a result of the application of multivariate statistical methods used in the identification of the input sources of heavy metals, it was determined that $\mathrm{Cu}, \mathrm{Zn}$ and $\mathrm{Pb}$ levels in the studied region were slightly affected by anthropogenic and natural inputs. In addition, using the geospatial analysis technique, the hot-spot areas of the distribution of metal concentrations were determined. In the geospatial distribution map, higher $\mathrm{Cu}, \mathrm{Zn}, \mathrm{Fe}$ and $\mathrm{Pb}$ contents were observed in the Eastern Black Sea region mainly due to the important mineral deposits that are operated and not operated. Finally, the results of this study will be very useful and informative for future studies as they contain updated data on the levels of metal pollution in the marine environment in the area under investigation. 
487 The authors are grateful to the Trabzon Fisheries Central Research Institute (SUMAE) for 488 their contribution to sediment sampling.

489

490

491

492

493

494

495

496

497

498

499

500

501

502

503

504

505

Authors' contributions AA, GA, MŞ, ET, OKK: Sample collection, analysis and manuscript preparation. AA, GA, MŞ, EC, HB: data interpretation and editing of the manuscript. AA, OKK, GA, ET: identification of collected samples. AA, GA, MŞ, HB, EC: analysis and data interpretation. HK, MŞ, AA: visualization. MŞ, EC, OKK: manuscript editing.

Funding No funding.

Competing interests The authors declare that they have no conflict of interest.

Ethics approval Not applicable.

Consent to participate Not applicable.

Consent for publication Not applicable.

Availability of data and materials The datasets used and analyzed during the current study are available from the corresponding author on reasonable request. 


\section{References}

507

508

509

510

511

512

513

514

515

516

517

518

519

520

521

522

523

524

525

526

527

Ahamad MI, Song J, Sun H, et al (2020) Contamination level, ecological risk, and source identification of heavy metals in the hyporheic zone of the Weihe River, China. Int $\mathbf{J}$ Environ Res Public Health 17:1070

Akyüz T, Akyüz S, Bassari A (2001) Radioisotope excited EDXRF analysis of sediment core samples from the southern part of the Black Sea+. J Radioanal Nucl Chem 250:129-137

Akyüz T, Akyüz S, Mukhamedshina NM, Mirsagatova AA (2003) Energy dispersive X-ray fluorescence and neutron activation analyses of sediments from the Turkish coast of the west Black Sea

Al-Haidarey MJS, Hassan FM, Al-Kubaisey ARA, Douabul AAZ (2010) The geoaccumulation index of some heavy metals in Al-Hawizeh Marsh, Iraq. J Chem $7: S 157-S 162$

Ali MM, Ali ML, Islam MS, Rahman MZ (2016) Preliminary assessment of heavy metals in water and sediment of Karnaphuli River, Bangladesh. Environ Nanotechnology, Monit Manag 5:27-35

Alkan N, Alkan A, Akbaş U, Fisher A (2015) Metal pollution assessment in sediments of the southeastern Black Sea Coast of Turkey. Soil Sediment Contam An Int J 24:290-305

Alkan N, Alkan A, Demirak A, Bahloul M (2020) Metals/metalloid in marine sediments, bioaccumulating in macroalgae and a mussel. Soil Sediment Contam An Int J 29:569594

Bakan G, Büyükgüngör H (2000) The black sea. Mar Pollut Bull 41:24-43

Baltas H, Kiris E, Sirin M (2017a) Determination of radioactivity levels and heavy metal 
concentrations in seawater, sediment and anchovy (Engraulis encrasicolus) from the Black Sea in Rize, Turkey. Mar Pollut Bull 116:. doi: 10.1016/j.marpolbul.2017.01.016

Baltas H, Kiris E, Sirin M (2017b) Determination of radioactivity levels and heavy metal concentrations in seawater, sediment and anchovy (Engraulis encrasicolus) from the Black Sea in Rize, Turkey. Mar Pollut Bull 116:. doi: 10.1016/j.marpolbul.2017.01.016

Baltas H, Sirin M, Dalgic G, et al (2017c) Assessment of metal concentrations $(\mathrm{Cu}, \mathrm{Zn}$, and $\mathrm{Pb}$ ) in seawater, sediment and biota samples in the coastal area of Eastern Black Sea, Turkey. Mar Pollut Bull. doi: 10.1016/j.marpolbul.2017.06.059

Baltas H, Sirin M, Gökbayrak E, Ozcelik AE (2020) A case study on pollution and a human health risk assessment of heavy metals in agricultural soils around Sinop province, Turkey. Chemosphere 241:. doi: 10.1016/j.chemosphere.2019.125015

Bat L, Yesim Özkan E, Can Öztekin H (2015) The contamination status of trace metals in Sinop coast of the Black Sea, Turkey. Casp J Environ Sci 13:1-10

Bryan GW t (1976) Heavy metal contamination in the sea. Mar Pollut 3:185-302

Cai L-M, Wang Q-S, Wen H-H, et al (2019) Heavy metals in agricultural soils from a typical township in Guangdong Province, China: Occurrences and spatial distribution. Ecotoxicol Environ Saf 168:184-191

Cai L, Xu Z, Bao P, et al (2015) Multivariate and geostatistical analyses of the spatial distribution and source of arsenic and heavy metals in the agricultural soils in Shunde, Southeast China. J Geochemical Explor 148:189-195

Cai L, Xu Z, Ren M, et al (2012) Source identification of eight hazardous heavy metals in agricultural soils of Huizhou, Guangdong Province, China. Ecotoxicol Environ Saf 78:2- 
551 Çevik U, Damla N, Kobya AI, et al (2008) Assessment of metal element concentrations in 552 mussel (M. galloprovincialis) in Eastern Black Sea, Turkey. J Hazard Mater 160:396553 401

Chabukdhara M, Nema AK (2013) Heavy metals assessment in urban soil around industrial clusters in Ghaziabad, India: probabilistic health risk approach. Ecotoxicol Environ Saf $87: 57-64$

Chakravarty M, Patgiri AD (2009) Metal pollution assessment in sediments of the Dikrong River, NE India. J Hum Ecol 27:63-67

Chandrasekaran A, Ravisankar R, Harikrishnan N, et al (2015) Multivariate statistical analysis of heavy metal concentration in soils of Yelagiri Hills, Tamilnadu, India Spectroscopical approach. Spectrochim Acta - Part A Mol Biomol Spectrosc 137:589_ 600. doi: 10.1016/j.saa.2014.08.093

Chatterjee M, Silva Filho E V, Sarkar SK, et al (2007) Distribution and possible source of trace elements in the sediment cores of a tropical macrotidal estuary and their ecotoxicological significance. Environ Int 33:346-356

Chen C-W, Kao C-M, Chen C-F, Dong C-D (2007) Distribution and accumulation of heavy metals in the sediments of Kaohsiung Harbor, Taiwan. Chemosphere 66:1431-1440

Chen L, Zhou S, Wu S, et al (2018) Combining emission inventory and isotope ratio analyses for quantitative source apportionment of heavy metals in agricultural soil. Chemosphere 204:140-147

Costa-Böddeker S, Hoelzmann P, de Stigter HC, et al (2018) The hidden threat of heavy 
Cukrov N, Frančišković-Bilinski S, Hlača B, Barišić D (2011) A recent history of metal accumulation in the sediments of Rijeka harbor, Adriatic Sea, Croatia. Mar Pollut Bull $62: 154-167$

Dalgic G, Kiris E, Baltas H, Sirin M (2018) Determination of radiological hazard parameters in sea snails (Rapana venosa) in the East Black Sea Coast of Turkey. Mar Pollut Bull $135: 441-445$

Delgado J, Nieto JM, Boski T (2010) Analysis of the spatial variation of heavy metals in the Guadiana Estuary sediments (SW Iberian Peninsula) based on GIS-mapping techniques. Estuar Coast Shelf Sci 88:71-83

El-Sorogy AS, Youssef M, Al-Kahtany K, Saleh MM (2020) Distribution, source, contamination, and ecological risk status of heavy metals in the Red Sea-Gulf of Aqaba coastal sediments, Saudi Arabia. Mar Pollut Bull 158:111411

Ergül HA, Topcuoğlu S, Ölmez E, Kırbaşoğlu Ç (2008) Heavy metals in sinking particles and bottom sediments from the eastern Turkish coast of the Black Sea. Estuar Coast Shelf Sci 78:396-402

Fakhradini SS, Moore F, Keshavarzi B, Lahijanzadeh A (2019) Polycyclic aromatic hydrocarbons (PAHs) in water and sediment of Hoor Al-Azim wetland, Iran: a focus on source apportionment, environmental risk assessment, and sediment-water partitioning. Environ Monit Assess 191:1-18 
Filzek PDB, Spurgeon DJ, Broll G, et al (2004) Pedological characterisation of sites along a transect from a primary cadmium/lead/zinc smelting works. Ecotoxicology 13:725-737

Gao L, Wang Z, Zhu A, et al (2019) Quantitative source identification and risk assessment of trace elements in soils from Leizhou Peninsula, South China. Hum Ecol Risk Assess An Int J 25:1832-1852

Ghani SAA (2015) Trace metals in seawater, sediments and some fish species from Marsa Matrouh Beaches in north-western Mediterranean coast, Egypt. Egypt J Aquat Res $41: 145-154$

Gholizadeh M, Patimar R (2018) Ecological risk assessment of heavy metals in surface sediments from the Gorgan Bay, Caspian Sea. Mar Pollut Bull 137:662-667

Görür FK, Keser R, Akcay N, Dizman S (2012) Radioactivity and heavy metal concentrations of some commercial fish species consumed in the Black Sea Region of Turkey. Chemosphere 87:356-361

Hakanson L (1980) An ecological risk index for aquatic pollution control. A sedimentological approach. Water Res 14:975-1001

Han X, Lu X (2017) Spatial distribution, environmental risk and source of heavy metals in street dust from an industrial city in semi-arid area of China. Arch Environ Prot 43:10 19

Idris AM (2008) Combining multivariate analysis and geochemical approaches for assessing heavy metal level in sediments from Sudanese harbors along the Red Sea coast. Microchem J 90:159-163 
617

618

619

620

621

622

623

624

625

626

627

628

629

630

631

632

633

634

635

636

637

638

Järup L (2003) Hazards of heavy metal contamination. Br Med Bull 68:167-182

Jia Y, Wang L, Qu Z, Yang Z (2018) Distribution, contamination and accumulation of heavy metals in water, sediments, and freshwater shellfish from Liuyang River, Southern China. Environ Sci Pollut Res 25:7012-7020

Karbasdehi VN, Dobaradaran S, Nabipour I, et al (2016) A new bioindicator, shell of Trachycardium lacunosum, and sediment samples to monitors metals (Al, Zn, Fe, Mn, $\mathrm{Ni}, \mathrm{V}, \mathrm{Co}, \mathrm{Cr}$ and $\mathrm{Cu}$ ) in marine environment: The Persian Gulf as a case. J Environ Heal Sci Eng 14:1-12

Kelepertzis E (2014) Accumulation of heavy metals in agricultural soils of Mediterranean: Insights from Argolida basin, Peloponnese, Greece. Geoderma 221-222:82-90. doi: 10.1016/j.geoderma.2014.01.007

Krauskopf KB (1985) Introduction to geochemistry.- Ind edition. Mc Grow-Hill B company ISBN 007-y 66382-66383

Kumar SB, Padhi RK, Mohanty AK, Satpathy KK (2017) Elemental distribution and trace metal contamination in the surface sediment of south east coast of India. Mar Pollut Bull 114:1164-1170. doi: 10.1016/j.marpolbul.2016.10.038

Kusin FM, Azani NNM, Hasan SNMS, Sulong NA (2018) Distribution of heavy metals and metalloid in surface sediments of heavily-mined area for bauxite ore in Pengerang, Malaysia and associated risk assessment. Catena 165:454-464

Liu C-W, Lin K-H, Kuo Y-M (2003) Application of factor analysis in the assessment of groundwater quality in a blackfoot disease area in Taiwan. Sci Total Environ 313:77-89

Long ER, MacDonald DD, Smith SL, Calder FD (1995) Incidence of adverse biological 
effects within ranges of chemical concentrations in marine and estuarine sediments. Environ Manage 19:81-97

641

642

643

644

645

646

647

648

649

650

651

652

653

654

655

656

657

658

659

660

Lu X, Li LY, Wang L, et al (2009a) Contamination assessment of mercury and arsenic in roadway dust from Baoji, China. Atmos Environ 43:2489-2496

Lu X, Pan H, Wang Y (2017) Pollution evaluation and source analysis of heavy metal in roadway dust from a resource-typed industrial city in Northwest China. Atmos Pollut Res 8:587-595

Lu X, Wang L, Lei K, et al (2009b) Contamination assessment of copper, lead, zinc, manganese and nickel in street dust of Baoji, NW China. J Hazard Mater 161:1058-1062

Lu X, Wang L, Li LY, et al (2010) Multivariate statistical analysis of heavy metals in street dust of Baoji, NW China. J Hazard Mater 173:744-749

Lu X, Zhang X, Li LY, Chen H (2014) Assessment of metals pollution and health risk in dust from nursery schools in Xi'an, China. Environ Res 128:27-34. doi: 10.1016/j.envres.2013.11.007

Ma X, Zuo H, Tian M, et al (2016) Assessment of heavy metals contamination in sediments from three adjacent regions of the Yellow River using metal chemical fractions and multivariate analysis techniques. Chemosphere 144:264-272

Macdonald DD, Carr RS, Calder FD, et al (1996) Development and evaluation of sediment quality guidelines for Florida coastal waters. Ecotoxicology 5:253-278

Mamut A, Eziz M, Mohammad A, Anayit M (2017) The spatial distribution, contamination, and ecological risk assessment of heavy metals of farmland soils in KarashaharBaghrash oasis, northwest China. Hum Ecol Risk Assess 23:1300-1314. doi: 
662

663

664

665

666

667

668

669

670

671

672

673

674

675

676

677

678

679

680

681

682

Marcinkonis S, Baltrenaite E, Lazauskas S (2011) Extraction and mapping of soil factors using factor analysis and geostatistical analysis on intensively manured heterogenous soils. Pol J Env Stud 20:701-708

Mülayim A, Balkıs H (2015) Toxic metal (Pb, Cd, Cr, and $\mathrm{Hg}$ ) levels in Rapana venosa (Valenciennes, 1846), Eriphia verrucosa (Forskal, 1775), and sediment samples from the Black Sea littoral (Thrace, Turkey). Mar Pollut Bull 95:215-222

Muller G (1969) Index of geoaccumulation in sediments of the Rhine River. GeoJournal 2:108-118

Ni M, Mao R, Jia Z, et al (2018) Heavy metals in soils of Hechuan County in the upper Yangtze (SW China): Comparative pollution assessment using multiple indices with high-spatial-resolution sampling. Ecotoxicol Environ Saf 148:644-651. doi: 10.1016/j.ecoenv.2017.11.009

Nour HE, El-Sorogy AS, Abd El-Wahab M, et al (2019) Contamination and ecological risk assessment of heavy metals pollution from the Shalateen coastal sediments, Red Sea, Egypt. Mar Pollut Bull 144:167-172

Omwene PI, Öncel MS, Çelen M, Kobya M (2018) Heavy metal pollution and spatial distribution in surface sediments of Mustafakemalpaşa stream located in the world's largest borate basin (Turkey). Chemosphere

Otansev P, Taşkın H, Başsarı A, Varinlioğlu A (2016) Distribution and environmental impacts of heavy metals and radioactivity in sediment and seawater samples of the Marmara Sea. Chemosphere 154:266-275 
Ozkan EY, Buyukisik B (2012) Geochemical and statistical approach for assessing heavy metal accumulation in the southern Black Sea sediments. Ekoloji 21:11-24

Ozseker K, Eruz C (2017) Pollution assessment of toxic metals in representative limnetic ecosystem sediments in the southeastern Black Sea, Turkey. CLEAN-Soil, Air, Water $45: 1700407$

Ozseker K, Seyhan K, Eruz C (2016) ECOLOGICAL RISK ASSESSMENT AND SPATIAL DISTRIBUTION OF HEAVY METALS IN SEDIMENT AND PORE WATER AROUND TRABZON HARBOR, TURKEY. Fresenius Environ Bull 25:

Pejman A, Bidhendi GN, Ardestani M, et al (2015) A new index for assessing heavy metals contamination in sediments: a case study. Ecol Indic 58:365-373

Qin F, Ji H, Li Q, et al (2014) Evaluation of trace elements and identification of pollution sources in particle size fractions of soil from iron ore areas along the Chao River. J Geochemical Explor 138:33-49

Ravisankar R, Sivakumar S, Chandrasekaran A, et al (2014) Spatial distribution of gamma radioactivity levels and radiological hazard indices in the East Coastal sediments of Tamilnadu, India with statistical approach. Radiat Phys Chem 103:89-98

Sarı E, Çağatay MN, Acar D, et al (2018) Geochronology and sources of heavy metal pollution in sediments of Istanbul Strait (Bosporus) outlet area, SW Black Sea, Turkey. Chemosphere 205:387-395

Savitha S, Srinivasalu S, Suresh S, Jayamoorthy K (2018) Distribution of heavy metals in the marine sediments of various sites in Karaichalli Island, Tuticorin, Gulf of Mannar, India. Silicon 10:1419-1425 
Şirin M (2019) Evaluation of radioactive pollution in sediment samples of Borçka Dam Lake, Turkey. Cumhur Sci J 40:624-639

Soliman NF, Nasr SM, Okbah MA (2015) Potential ecological risk of heavy metals in sediments from the Mediterranean coast, Egypt. J Environ Heal Sci Eng 13:1-12

Song J, Liu Q, Sheng Y (2019) Distribution and risk assessment of trace metals in riverine surface sediments in gold mining area. Environ Monit Assess 191:1-13

Sun C, Zhang Z, Cao H, et al (2019) Concentrations, speciation, and ecological risk of heavy metals in the sediment of the Songhua River in an urban area with petrochemical industries. Chemosphere 219:538-545

Sur M, Sur Hİ, Apak R, Erçağ E (2012) The pollution status of bottom surface sediments along the Turkish coast of the Black Sea. Turkish J Fish Aquat Sci 12:453-460

Tholkappian M, Ravisankar R, Chandrasekaran A, et al (2018) Assessing heavy metal toxicity in sediments of Chennai Coast of Tamil Nadu using Energy Dispersive X-Ray Fluorescence Spectroscopy (EDXRF) with statistical approach. Toxicol reports 5:173182

Tian K, Huang B, Xing Z, Hu W (2017) Geochemical baseline establishment and ecological risk evaluation of heavy metals in greenhouse soils from Dongtai, China. Ecol Indic $72: 510-520$

Tian K, Wu Q, Liu P, et al (2020) Ecological risk assessment of heavy metals in sediments and water from the coastal areas of the Bohai Sea and the Yellow Sea. Environ Int $136: 105512$

Tomlinson DL, Wilson JG, Harris CR, Jeffrey DW (1980) Problems in the assessment of 

heavy-metal levels in estuaries and the formation of a pollution index. Helgoländer meeresuntersuchungen 33:566

Topcuoglu S, Ergül HA, Baysal A, et al (2003) Determination of radionuclide and heavy metal concentrations in biota and sediment samples from Pazar and Rize stations in the eastern Black Sea. Fresenius Environ Bull 12:695-699

Turekian KK (1971) Part 1. Transport processes and reservoirs. 2. Rivers. tributaries, and estuaries. Impingement man Ocean D W Hood(Ed) New York, Wiley-Interscience 9-73

Ungureanu T, Iancu GO, Pintilei M, Chicoș MM (2017) Spatial distribution and geochemistry of heavy metals in soils: a case study from the NE area of Vaslui county, Romania. J Geochemical Explor 176:20-32

Ustaoğlu F, Islam MS (2020) Potential toxic elements in sediment of some rivers at Giresun, Northeast Turkey: A preliminary assessment for ecotoxicological status and health risk. Ecol Indic 113:106237

Ustun Odabaşı S, Şentürk İ, Maryam B, et al (2018) Temporal variation of mercury in Turkish Black Sea waters and associated risk assessment. Glob NEST J 20:345-354

Varol M, Şen B (2012) Assessment of nutrient and heavy metal contamination in surface water and sediments of the upper Tigris River, Turkey. Catena 92:1-10

Wang J, Ye S, Laws EA, et al (2017) Surface sediment properties and heavy metal pollution assessment in the Shallow Sea Wetland of the Liaodong Bay, China. Mar Pollut Bull $120: 347-354$

Wang X, Zeng X, Chuanping L, et al (2016) Heavy metal contaminations in soil-rice system: source identification in relation to a sulfur-rich coal burning power plant in Northern 
Wardas M, Budek L, Rybicka EH (1996) Variability of heavy metals content in bottom sediments of the Wilga River, a tributary of the Vistula River (Krakow area, Poland). Appl Geochemistry 11:197-202

Xia F, Qu L, Wang T, et al (2018) Distribution and source analysis of heavy metal pollutants in sediments of a rapid developing urban river system. Chemosphere 207:218-228

Xu M, Wang R, Yang X, Yang H (2020) Spatial distribution and ecological risk assessment of heavy metal pollution in surface sediments from shallow lakes in East China. J Geochemical Explor 213:106490

Yi Y, Yang Z, Zhang S (2011) Ecological risk assessment of heavy metals in sediment and human health risk assessment of heavy metals in fishes in the middle and lower reaches of the Yangtze River basin. Environ Pollut 159:2575-2585

Yiğiterhan O, Murray JW (2008) Trace metal composition of particulate matter of the Danube River and Turkish rivers draining into the Black Sea. Mar Chem 111:63-76

Yu B, Lu X, Fan X, et al (2021) Analyzing environmental risk, source and spatial distribution of potentially toxic elements in dust of residential area in Xi'an urban area, China. Ecotoxicol Environ Saf 208:111679

Zhang H, Liu G, Shi W, Li J (2014) Soil heavy metal contamination and risk assessment around the Fenhe Reservoir, China. Bull Environ Contam Toxicol 93:182-186

Zhang M, Lu X, Chen H, et al (2015) Multi-element characterization and source identification of trace metal in road dust from an industrial city in semi-humid area of Northwest China. J Radioanal Nucl Chem 303:637-646 
Zhang P, Qin C, Hong X, et al (2018) Risk assessment and source analysis of soil heavy metal pollution from lower reaches of Yellow River irrigation in China. Sci Total Environ 633:1136-1147. doi: 10.1016/j.scitotenv.2018.03.228

Zhu H, Bing $\mathrm{H}, \mathrm{Wu} \mathrm{Y}$, et al (2019) The spatial and vertical distribution of heavy metal contamination in sediments of the Three Gorges Reservoir determined by anti-seasonal flow regulation. Sci Total Environ 664:79-88

Zhu X, Ji H, Chen Y, et al (2013) Assessment and sources of heavy metals in surface sediments of Miyun Reservoir, Beijing. Environ Monit Assess 185:6049-6062

Zhu Y, Lu X, Yang L, Wang L (2016) Accumulation and source of heavy metals in sediment of a reservoir near an industrial park of northwest China. Front Earth Sci 10:707-716

Zhuang S, Lu X (2020) Environmental Risk Evaluation and Source Identification of Heavy Metal (loid) s in Agricultural Soil of Shangdan Valley, Northwest China. Sustainability 12:5806 
793 Fig. 1 Map of the study area.

794 Fig. 2 The contribution of metals to the potential ecological risk.

795 Fig. 3 PCA loading plots for rotated components of heavy metals in sediment.

796 Fig. 4 Spatial distribution of heavy metal contents.

797

798

799

800

801

802

803

804

805

806

807

808

809

810

811

812

813

814

815

816

817

818 

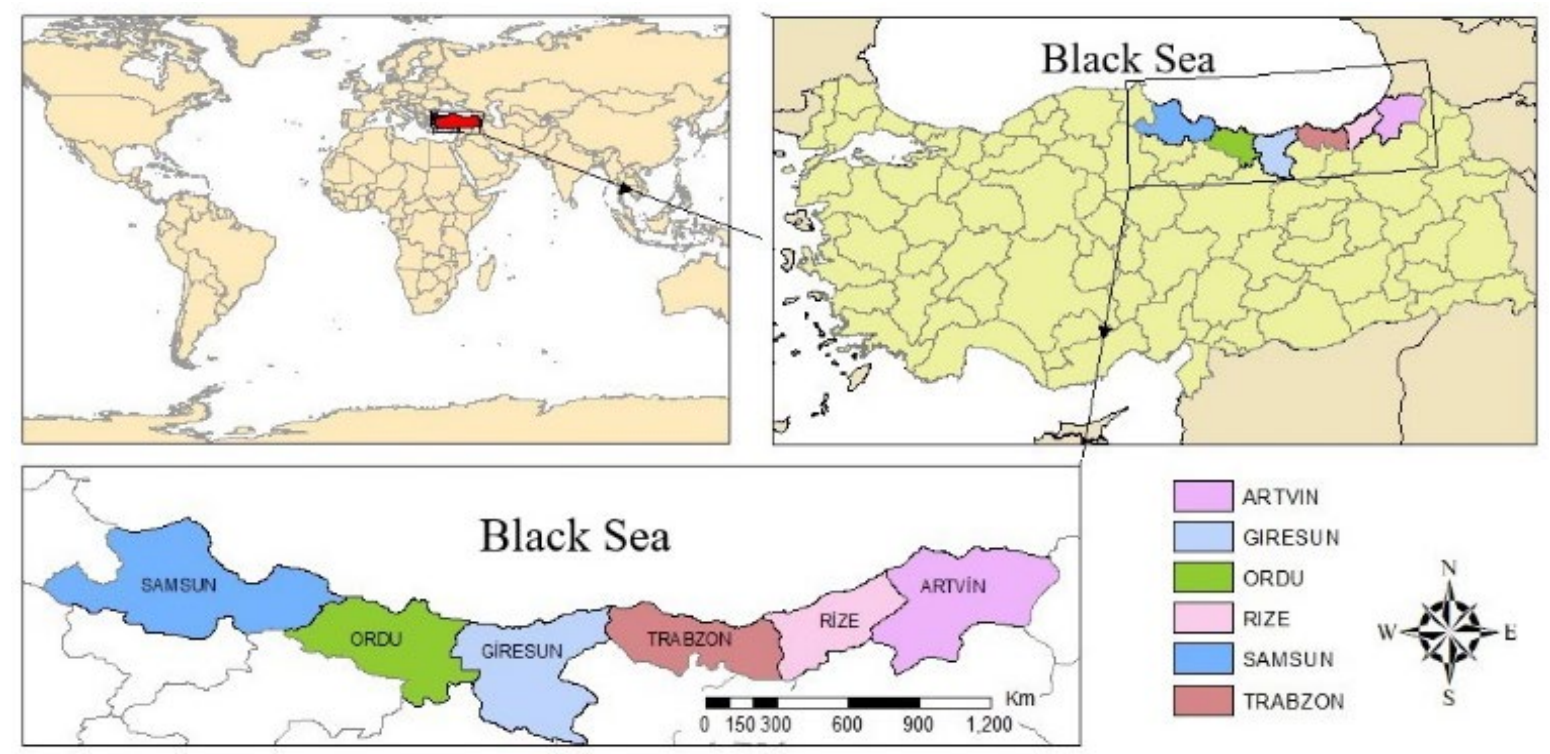

$822 \quad$ Fig. 1

823

824

825

826

827

828

829

830

831

832 


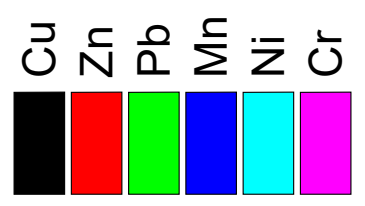

$33.28 \%$

833

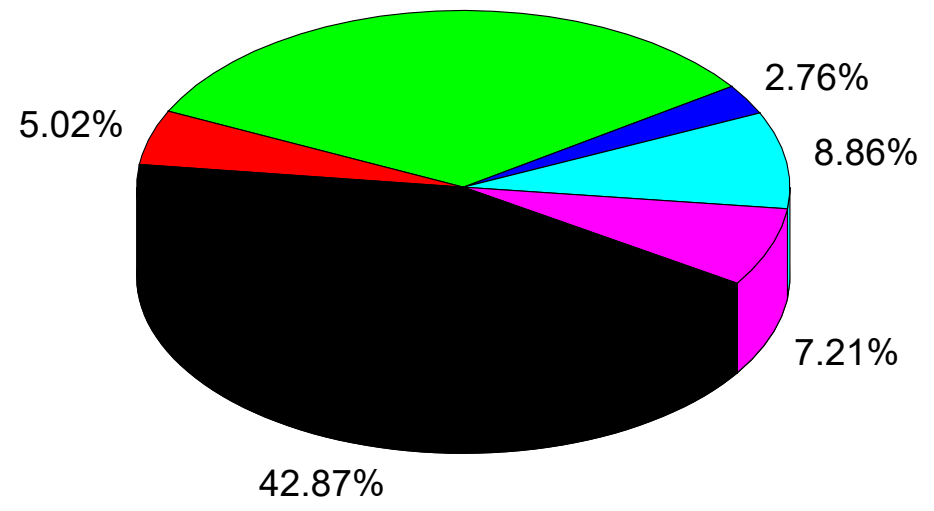

$834 \quad$ Fig. 2

835

836

837

838

839

840

841

842

843 


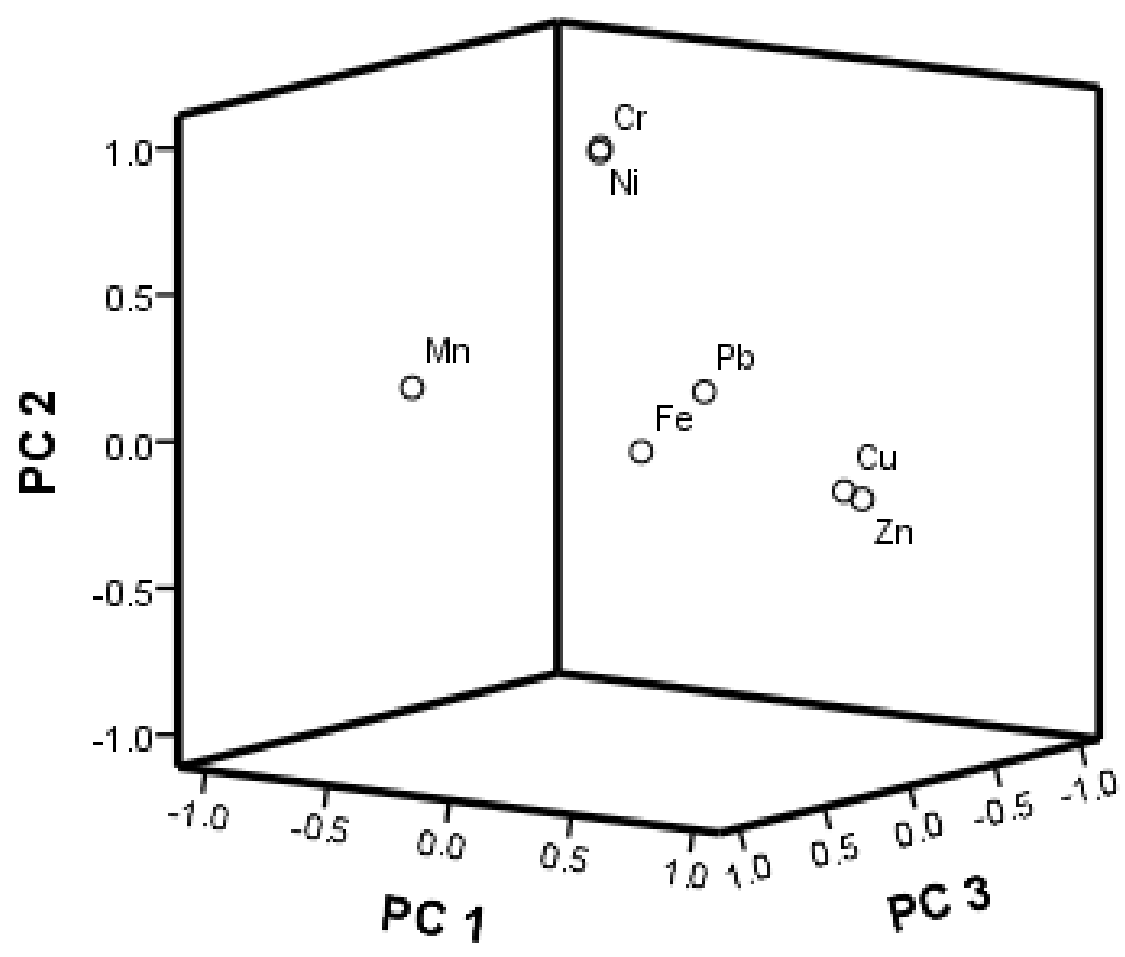

$846 \quad$ Fig. 3

847 

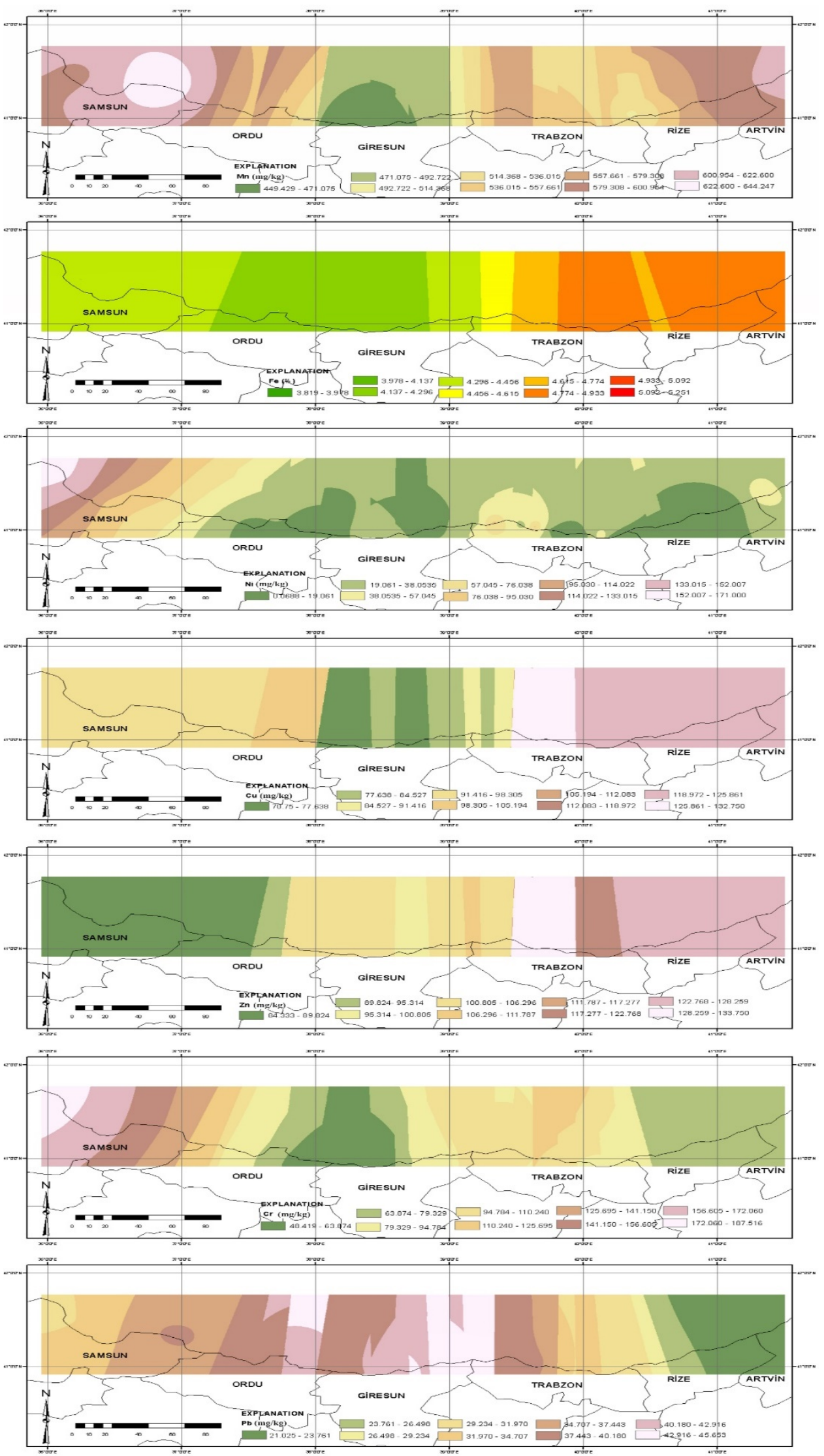

Fig. 4 
Table 1 Descriptive statistics of some properties and heavy metal content in sediments $(n=48)$.

\begin{tabular}{|c|c|c|c|c|c|c|c|c|c|c|c|}
\hline Elements & $\begin{array}{c}\text { Min } \\
\text { (mg/kg) }\end{array}$ & $\begin{array}{c}\text { Max } \\
\text { (mg/kg) }\end{array}$ & $\begin{array}{c}\text { Mean } \\
\text { (mg/kg) }\end{array}$ & $\begin{array}{c}\mathrm{SD}^{\mathrm{a}} \\
(\mathrm{mg} / \mathrm{kg})\end{array}$ & K-S test & Skewness & Kurtosis & \multicolumn{2}{|l|}{$\mathbf{C V}^{\mathbf{b}}$} & TEL $^{d}$ & $\mathbf{P E L}^{\mathrm{d}}$ \\
\hline $\mathbf{F e}$ & 34,300 & 60,000 & 46,000 & 7,000 & 0.47 & 0.18 & -0.37 & 15.22 & 47,000 & - & - \\
\hline $\mathbf{N i}$ & 8 & 171 & 34.38 & 43.79 & 1.34 & 2.42 & 6.15 & 127.37 & 80 & 15.9 & 42.8 \\
\hline $\mathbf{Z n}$ & 54 & 456 & 109.88 & 95.30 & 1.52 & 3.61 & 13.67 & 86.73 & 90 & 124.0 & 271 \\
\hline $\mathrm{Cr}$ & 19 & 306 & 87.31 & 83.72 & 1.29 & 1.61 & 1.76 & 95.89 & 100 & 52.3 & 160 \\
\hline $\mathbf{P b}$ & 13 & 83 & 32.31 & 19.27 & 0.64 & 0.90 & 2.20 & 59.64 & 20 & 30.2 & 112 \\
\hline
\end{tabular}

n: sampling size

${ }^{\mathrm{a}}$ Standard deviation (SD)

${ }^{\mathrm{b}}$ Coefficent of variation $(\mathrm{CV})(\%)$

${ }^{\mathrm{c}}$ Background value (BGV) of chemical elements in the shale (Krauskopf 1985)

d TEL: threshold effect level; PEL: probable effect level. Sediment quality guidelines (SQG) from Long et al., (1995) (Long et al. 1995) 
Table 2 Comparison of heavy metal concentrations $(\mathrm{mg} / \mathrm{kg})$ in sediments with the previous studies.

\begin{tabular}{|c|c|c|c|c|c|c|c|c|}
\hline Study Area & Mn & $\mathbf{F e}$ & $\mathbf{N i}$ & $\mathbf{C u}$ & $\mathbf{Z n}$ & $\mathrm{Cr}$ & $\mathbf{P b}$ & References \\
\hline $\begin{array}{l}\text { Turkey } \\
\text { (Eastern Black Sea Coast) }\end{array}$ & 446.9 & - & 23.4 & 3107.3 & 4259.5 & 40.2 & 208.2 & (Alkan et al. 2020) \\
\hline $\begin{array}{l}\text { Turkey } \\
\text { (Eastern Black Sea Coast) }\end{array}$ & 399 & - & 13.8 & 31.8 & 70.2 & 18.5 & 22.2 & (Alkan et al. 2015) \\
\hline $\begin{array}{l}\text { Turkey } \\
\text { (Eastern Black Sea Coast) }\end{array}$ & 1,031 & 94,660 & 18.75 & $2,278.4$ & 993.8 & 27.28 & 125.18 & (Çevik et al. 2008) \\
\hline $\begin{array}{l}\text { Turkey } \\
\text { (Eastern Black Sea Coast) }\end{array}$ & - & - & - & 576.31 & 357.02 & - & 97.33 & (Baltas et al. 2017c) \\
\hline $\begin{array}{l}\text { Iranian } \\
\text { (Caspian sea) }\end{array}$ & - & - & 16.6 & 16.8 & 29.5 & 17.9 & 7.4 & $\begin{array}{l}\text { (Gholizadeh and } \\
\text { Patimar 2018) }\end{array}$ \\
\hline $\begin{array}{l}\text { Egyptian } \\
\text { (Mediterranean coast) }\end{array}$ & 381 & 13,256 & 25.93 & 8.46 & 22.19 & 82.74 & 13.17 & (Soliman et al. 2015) \\
\hline $\begin{array}{l}\text { Egyptian } \\
\text { (Red sea) }\end{array}$ & 198.76 & $8,451.62$ & 17.52 & 9.43 & 44.15 & - & 11.43 & (Nour et al. 2019) \\
\hline $\begin{array}{l}\text { Saudi Arabia } \\
\text { (Red sea) }\end{array}$ & 184 & 3,374 & 14 & 30 & 24 & 39 & 6.6 & (El-Sorogy et al. 2020) \\
\hline $\begin{array}{l}\text { Turkey } \\
\text { (Middle and Eastern Black } \\
\text { Sea Coast) }\end{array}$ & 565.38 & 46,000 & 34.38 & 104.06 & 109.88 & 87.31 & 32.31 & Present study \\
\hline
\end{tabular}


Table 3 Calculated pollution indices due to heavy metal concentration.

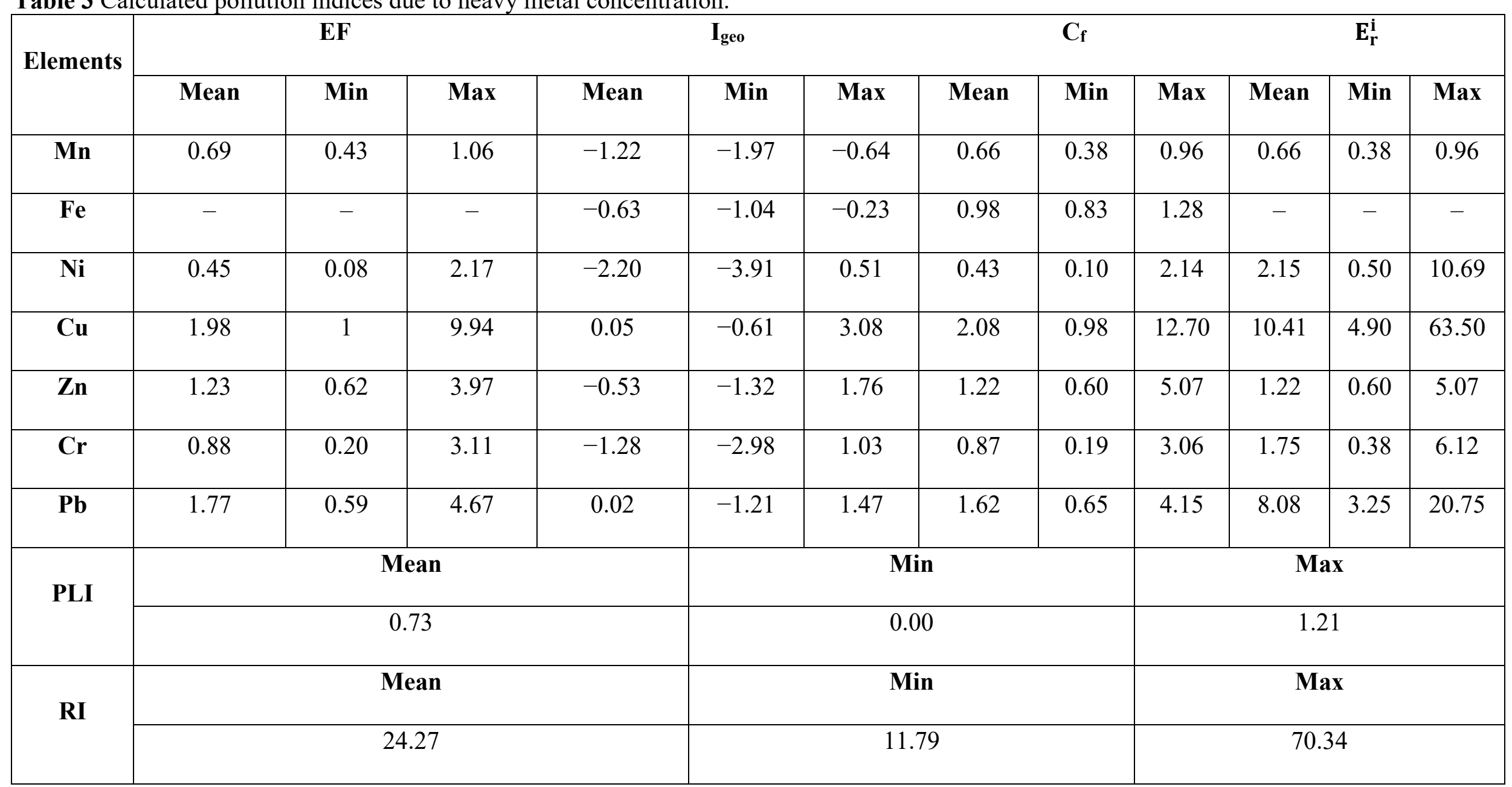


Table 4 Rotated component matrix of metals in sediments in the Middle and Eastern Black Sea.

\begin{tabular}{|c|c|c|c|}
\hline Parameter & PC1 & $\mathrm{PC} 2$ & PC3 \\
\hline $\mathrm{Mn}$ & -0.397 & 0.205 & 0.761 \\
\hline $\mathrm{Fe}$ & 0.501 & 0.069 & 0.701 \\
\hline $\mathrm{Ni}$ & -0.117 & 0.951 & 0.058 \\
\hline $\mathrm{Cu}$ & 0.968 & -0.094 & 0.180 \\
\hline $\mathrm{Zn}$ & 0.948 & -0.142 & 0.046 \\
\hline $\mathrm{Cr}$ & -0.072 & 0.951 & 0.128 \\
\hline $\mathrm{Pb}$ & -0.292 & -0.024 & -0.801 \\
\hline Eigenvalues & 2.695 & 2.206 & 1.099 \\
\hline$\%$ of variance & 38.503 & 31.515 & 15.694 \\
\hline Cumulative \% & 38.503 & 70.018 & 85.712 \\
\hline
\end{tabular}


Evaluation of ecological risk, source and spatial distribution of some heavy metals in marine sediments in the Middle and Eastern Black Sea region, Turkey

Aylin Apaydın" ${ }^{1}$ Hatice Kabaoğlu² $\cdot$ Gökhan Apaydın ${ }^{3 *} \cdot$ Murat Şirin $^{4}$, Erhan Cengiz $^{5} \cdot$ Oğuz Kağan Köksal ${ }^{6} \cdot$ Hasan Baltaş $^{4} \cdot$ Engin Tıraşoğlu $^{3}$

${ }^{1}$ Ministry of National Education, Trabzon, Turkey

${ }^{2}$ Gazi University, Faculty of Engineering, Department of Computer Engineering, Ankara, Turkey

${ }^{3}$ Karadeniz Technical University, Faculty of Science, Department of Physics, Trabzon, Turkey

${ }^{4}$ Recep Tayyip Erdogan University, Faculty of Arts and Science, Department of Physics, Rize, Turkey

${ }^{5}$ Alanya Alaaddin Keykubat University, Faculty of Engineering, Department of Fundamental Science, Antalya, Turkey

${ }^{6}$ Adıyaman University, Gölbaşı Vocational School, Department of Electricity and Energy, Adıyaman, Turkey

*Corresponding Author: gapaydin@ktu.edu.tr Orcid Number: 0000-0002-4647-344X 
Table S1 The geographical coordinates, locations and some physico-chemical parameters for the sampling locations.

\begin{tabular}{|c|c|c|c|c|c|c|}
\hline Code & Latitude & Longitude & Depth (m) & $\begin{array}{c}\text { Temperature } \\
\left({ }^{\circ} \mathrm{C}\right)\end{array}$ & $\begin{array}{c}\text { From coast } \\
\text { (sea mile) }\end{array}$ & Location name \\
\hline S1 & $41^{\circ} 16^{\prime} 250^{\prime \prime}$ & $36^{\circ} 28^{\prime} 972^{\prime \prime}$ & 15 & 9.38 & 1.2 & Samsun (Nitrogen industry) \\
\hline S2 & $41^{\circ} 46^{\prime} 154^{\prime \prime}$ & $35^{\circ} 57^{\prime} 282^{\prime \prime}$ & 20 & 9.18 & 2.0 & Kızılırmak Offshore \\
\hline S3 & $41^{\circ} 02^{\prime} 657^{\prime \prime}$ & $37^{\circ} 30^{\prime} 857^{\prime \prime}$ & 10 & 8.74 & 1.0 & Ordu-Fatsa Offshore \\
\hline S4 & $41^{\circ} 01^{\prime} 802^{\prime \prime}$ & $37^{\circ} 50^{\prime} 324^{\prime \prime}$ & 15 & 9.22 & 0.7 & Ordu-Boztepe \\
\hline S5 & $40^{\circ} 57^{\prime} 329^{\prime \prime}$ & $38^{\circ} 17^{\prime} 986^{\prime \prime}$ & 20 & 9.26 & 0.9 & Giresun-Yalı Village \\
\hline S6 & $40^{\circ} 55^{\prime} 97^{\prime \prime}$ & $38^{\circ} 24^{\prime} 240^{\prime \prime}$ & 30 & 9.64 & 0.7 & Giresun Offshore \\
\hline S7 & $40^{\circ} 58^{\prime} 714^{\prime \prime}$ & $38^{\circ} 43^{\prime} 958^{\prime \prime}$ & 15 & 9.68 & 0.9 & Giresun-Espiye \\
\hline S8 & $41^{\circ} 03^{\prime} 649^{\prime \prime}$ & $39^{\circ} 04^{\prime} 852^{\prime \prime}$ & 20 & 9.49 & 1.0 & Gireun-Eynesil \\
\hline S9 & $41^{\circ} 04^{\prime} 430^{\prime \prime}$ & $39^{\circ} 20^{\prime} 528^{\prime \prime}$ & 20 & 9.72 & 0.3 & Trabzon-Çarşıbaşı \\
\hline S10 & $41^{\circ} 03^{\prime} 048^{\prime \prime}$ & $39^{\circ} 33^{\prime} 994^{\prime \prime}$ & 15 & 9.67 & 0.8 & Trabzon-Darica \\
\hline S11 & $41^{\circ} 00^{\prime} 666^{\prime \prime}$ & $39^{\circ} 45^{\prime} 649^{\prime \prime}$ & 10 & 9.52 & 0.5 & Trabzon Değirmendere \\
\hline $\mathrm{S} 12$ & $40^{\circ} 56^{\prime} 245^{\prime \prime}$ & $40^{\circ} 04^{\prime} 190^{\prime \prime}$ & 15 & 9.91 & 0.2 & Trabzon-Araklı \\
\hline S13 & $40^{\circ} 55^{\prime} 943^{\prime \prime}$ & $40^{\circ} 12^{\prime} 548^{\prime \prime}$ & 20 & 10.18 & 0.5 & Trabzon-Çamburnu \\
\hline S14 & $41^{\circ} 02^{\prime} 63^{\prime \prime}$ & $40^{\circ} 32^{\prime} 447^{\prime \prime}$ & 30 & 9.60 & 0.9 & Rize \\
\hline $\mathrm{S} 15$ & $41^{\circ} 11^{\prime} 962^{\prime \prime}$ & $40^{\circ} 55^{\prime} 690^{\prime \prime}$ & 20 & 9.59 & 1.2 & Rize-Ardeşen \\
\hline $\mathrm{S} 16$ & $41^{\circ} 29^{\prime} 827^{\prime \prime}$ & $41^{\circ} 30^{\prime} 82^{\prime \prime}$ & 30 & 9.67 & 0.7 & Artvin-Kemalpaşa \\
\hline
\end{tabular}


Table S2 Comparison of the certified and the measured values $(\mathrm{mg} / \mathrm{kg}$ dry weight) for the sediment (NW-WQB-1) certified reference material (CRM).

\begin{tabular}{|c|c|c|c|}
\hline \multirow{2}{*}{ Elements } & \multicolumn{3}{|c|}{ Lake Ontario sediment } \\
\cline { 2 - 4 } & Certified values & Measured values & $\begin{array}{c}\text { Percentage of } \\
\text { recovery (\%) }\end{array}$ \\
\hline $\mathrm{Mn}$ & $2240(1847-2633)$ & 2257 & 100.8 \\
\hline $\mathrm{Ni}$ & $57.6(47.6-67.6)$ & 60.3 & 104.7 \\
\hline $\mathrm{Fe}$ & $43200(33700-52700)$ & 44100 & 102.1 \\
\hline $\mathrm{Cu}$ & $74.0(62.1-85.9)$ & 70.4 & 95.1 \\
\hline $\mathrm{Zn}$ & $258(208-308)$ & 268 & 103.9 \\
\hline $\mathrm{Cr}$ & $46.8(35.2-58.4)$ & 48.2 & 102.9 \\
\hline $\mathrm{Pb}$ & $79(69.5-88.5)$ & 75.4 & 95.4 \\
\hline
\end{tabular}


Table S3 Classification of EF, Igeo and CF.

\begin{tabular}{|c|c|c|c|c|c|}
\hline $\mathbf{E F}$ & Degree of enrichment & $\mathbf{I}_{\text {geo }}$ & Soil quality & $\mathbf{C F}$ & Degree of soil pollution \\
\hline $\mathrm{EF}<1$ & No enrichment & $\mathrm{I}_{\text {geo }} \leq 0$ & Unpolluted & $\mathrm{CF}<1$ & Minimal contamination \\
\hline $\mathrm{EF}<3$ & Minimal enrichment & $0<$ Igeo $_{\text {g }}<1$ & Unpolluted to moderately contaminated & $1<\mathrm{CF}<3$ & Moderate contamination \\
\hline$E F=3-5$ & Moderate enrichment & $1<$ Igeo $_{\text {ge }}<2$ & Moderately polluted & $3<\mathrm{CF}<6$ & Substantial contamination \\
\hline $\mathrm{EF}=5-10$ & Slightly severe enrichment & $2<$ Igeo $_{\text {ge }}<3$ & Moderately to seriously polluted & $\mathrm{CF}>6$ & Very high contamination \\
\hline$E F=10-25$ & Severe enrichment & $3<$ Igeo $_{\text {ge }}<4$ & Seriously polluted & & \\
\hline$E F=25-50$ & Very severe enrichment & $4<$ Igeo $_{\text {ge }}<5$ & Seriously to excessively polluted & & \\
\hline $\mathrm{EF}>50$ & Excessively severe enrichment & $5<$ Igeo & Excessively polluted & & \\
\hline
\end{tabular}


Table S4 The classification of $E_{r}{ }^{i}$ and $R I$

\begin{tabular}{llll}
\hline $\mathbf{E}_{\mathbf{r}}{ }^{i}$ & Ecological risk grade & RI & Ecological risk grade \\
\hline $\mathrm{E}_{\mathrm{r}}^{\mathrm{i}}<15$ & Low & $\mathrm{RI}<50$ & Low \\
$15 \leq \mathrm{E}_{\mathrm{r}}^{\mathrm{i}}<30$ & Moderate & $50 \leq \mathrm{RI}<100$ & Moderate \\
$30 \leq \mathrm{E}_{\mathrm{r}}^{\mathrm{i}}<60$ & Considerable & $100 \leq \mathrm{RI}<200$ & Considerable \\
$60 \leq \mathrm{E}_{\mathrm{r}}^{\mathrm{i}}<120$ & High & $\mathrm{RI} \geq 200$ & High \\
$\mathrm{E}_{\mathrm{r}}^{\mathrm{i}} \geq 120$ & Very high & & \\
\hline
\end{tabular}


Table S5 Pearson correlation coefficients between metals in soils.

\begin{tabular}{|c|c|c|c|c|c|c|c|c|c|}
\hline & Mn & $\mathrm{Fe}$ & $\mathbf{N i}$ & $\mathrm{Cu}$ & Zn & $\mathrm{Cr}$ & $\mathbf{P b}$ & Depth & Distance \\
\hline Mn & 1 & & & & & & & & \\
\hline $\mathrm{Fe}$ & 0.271 & 1 & & & & & & & \\
\hline $\mathbf{N i}$ & 0.320 & -0.037 & 1 & & & & & & \\
\hline $\mathrm{Cu}$ & -0.211 & $0.552^{*}$ & -0.173 & 1 & & & & & \\
\hline Zn & -0.245 & 0.421 & -0.212 & $0.973^{* *}$ & 1 & & & & \\
\hline $\mathrm{Cr}$ & 0.273 & 0.189 & $0.845^{* *}$ & -0.155 & $0.960^{* *}$ & 1 & & & \\
\hline $\mathbf{P b}$ & -0.343 & $-0.574^{*}$ & -0.076 & -0.414 & -0.248 & -0.089 & 1 & & \\
\hline Depth & -0.302 & -0.024 & 0.040 & 0.061 & 0.069 & -0.078 & -0.090 & 1 & \\
\hline Distance & 0.157 & -0.093 & $0.615^{*}$ & -0.235 & -0.224 & $0.529^{*}$ & -0.063 & 0.041 & 1 \\
\hline
\end{tabular}

*** Correlation is significant at the 0.01 level (two-tailed).

${ }^{*}$ Correlation is significant at the 0.05 level (two-tailed). 
Figures
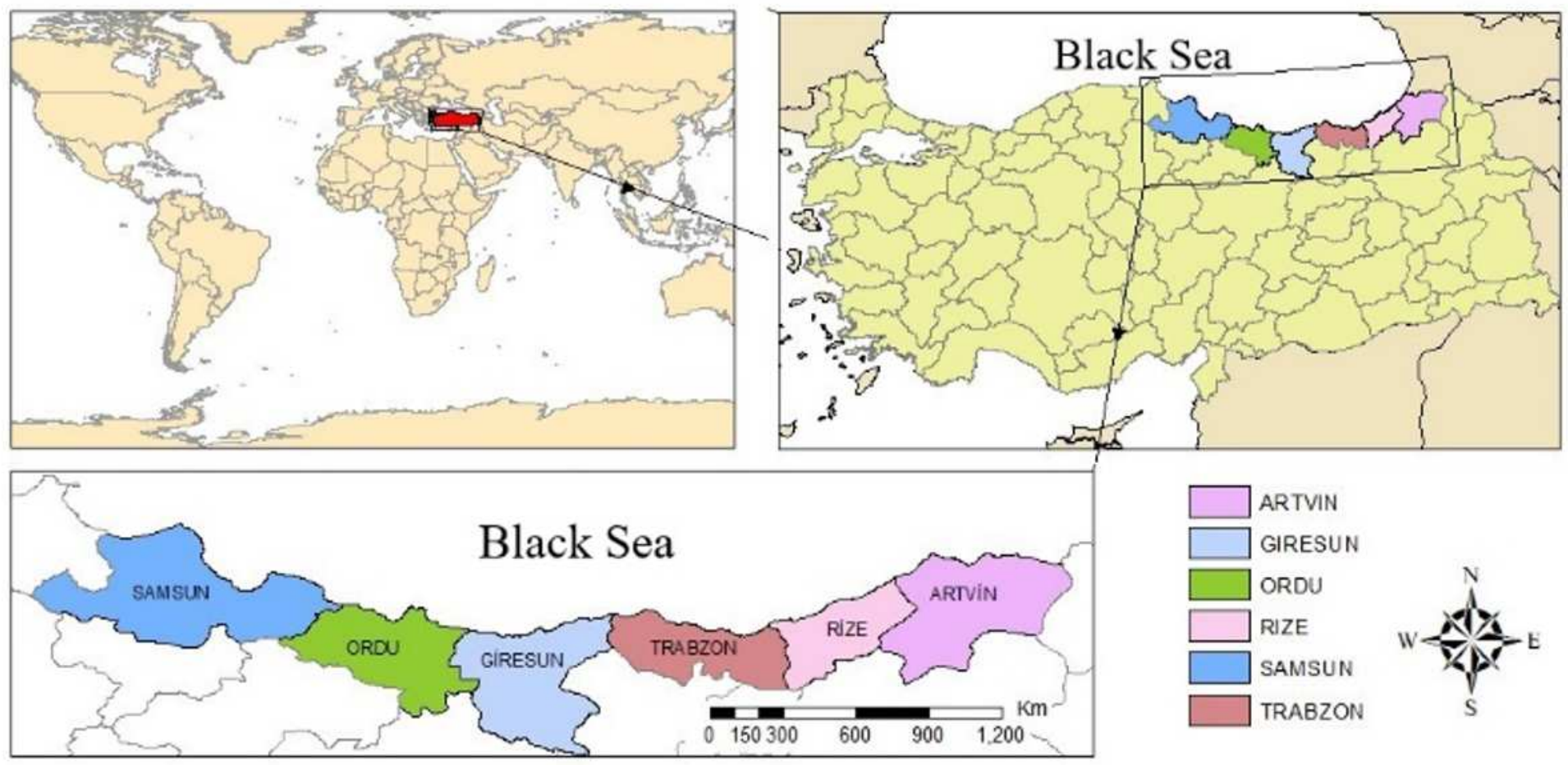

\section{Figure 1}

Map of the study area. Note: The designations employed and the presentation of the material on this map do not imply the expression of any opinion whatsoever on the part of Research Square concerning the legal status of any country, territory, city or area or of its authorities, or concerning the delimitation of its frontiers or boundaries. This map has been provided by the authors. 

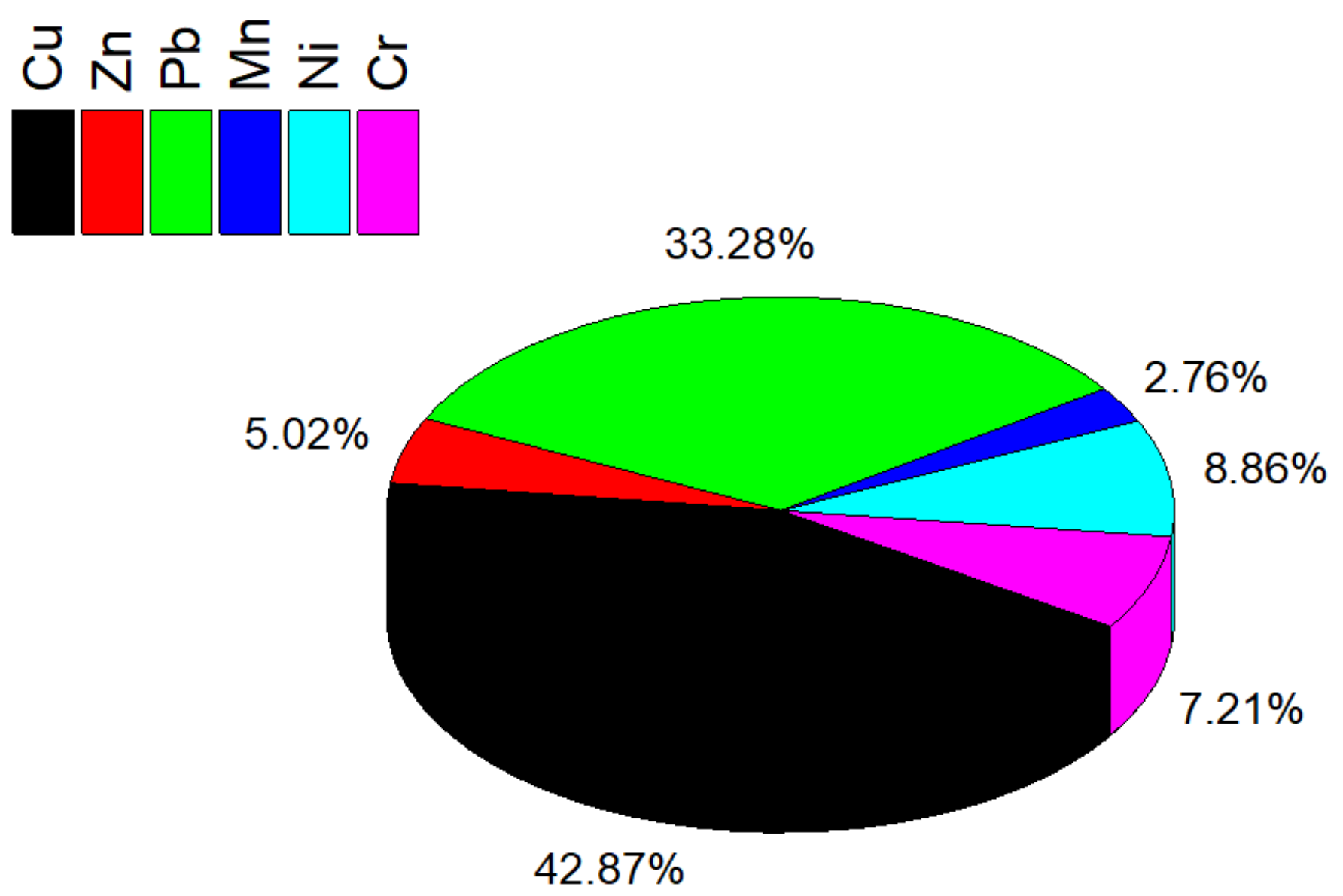

Figure 2

The contribution of metals to the potential ecological risk. 


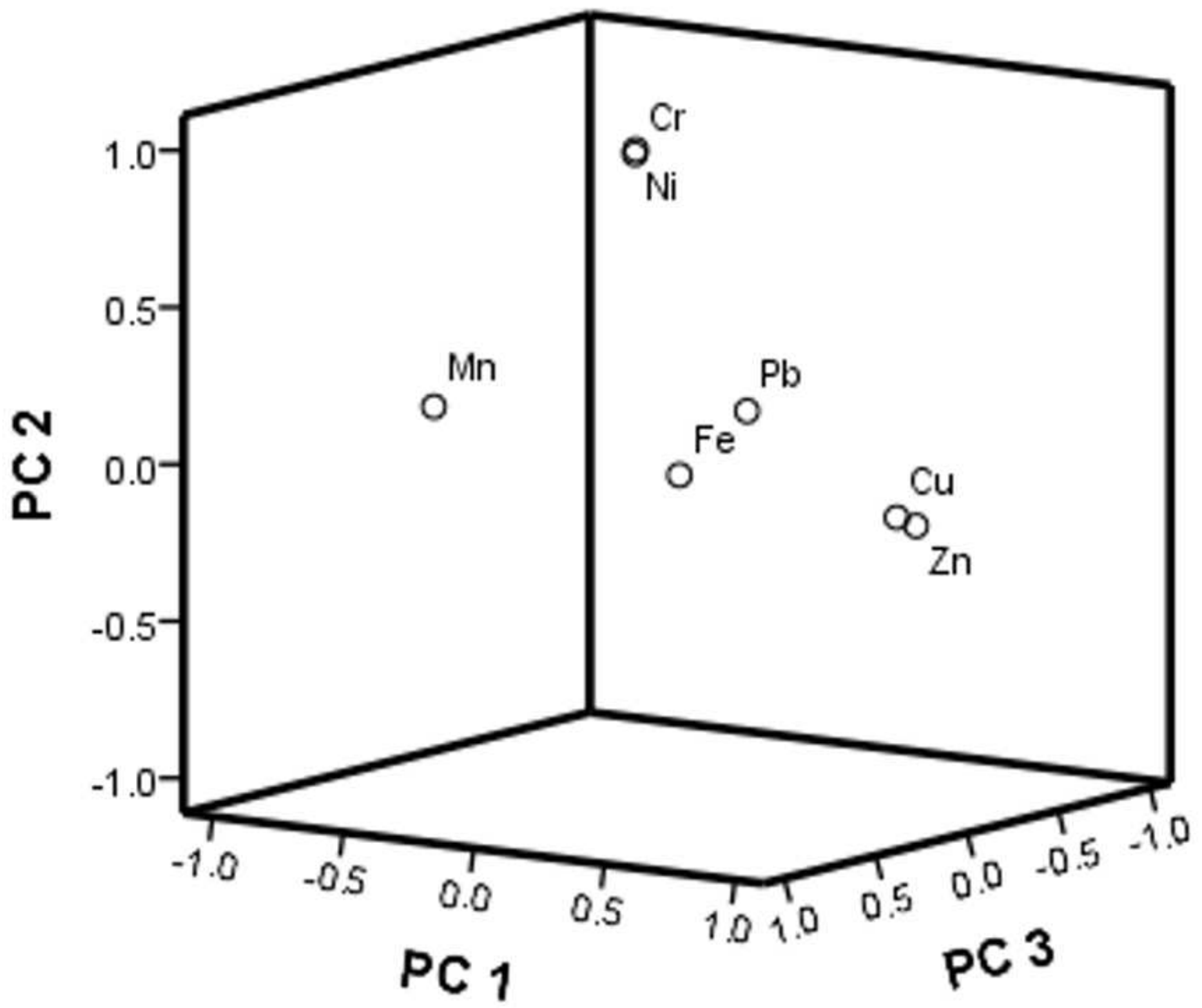

Figure 3

PCA loading plots for rotated components of heavy metals in sediment. 

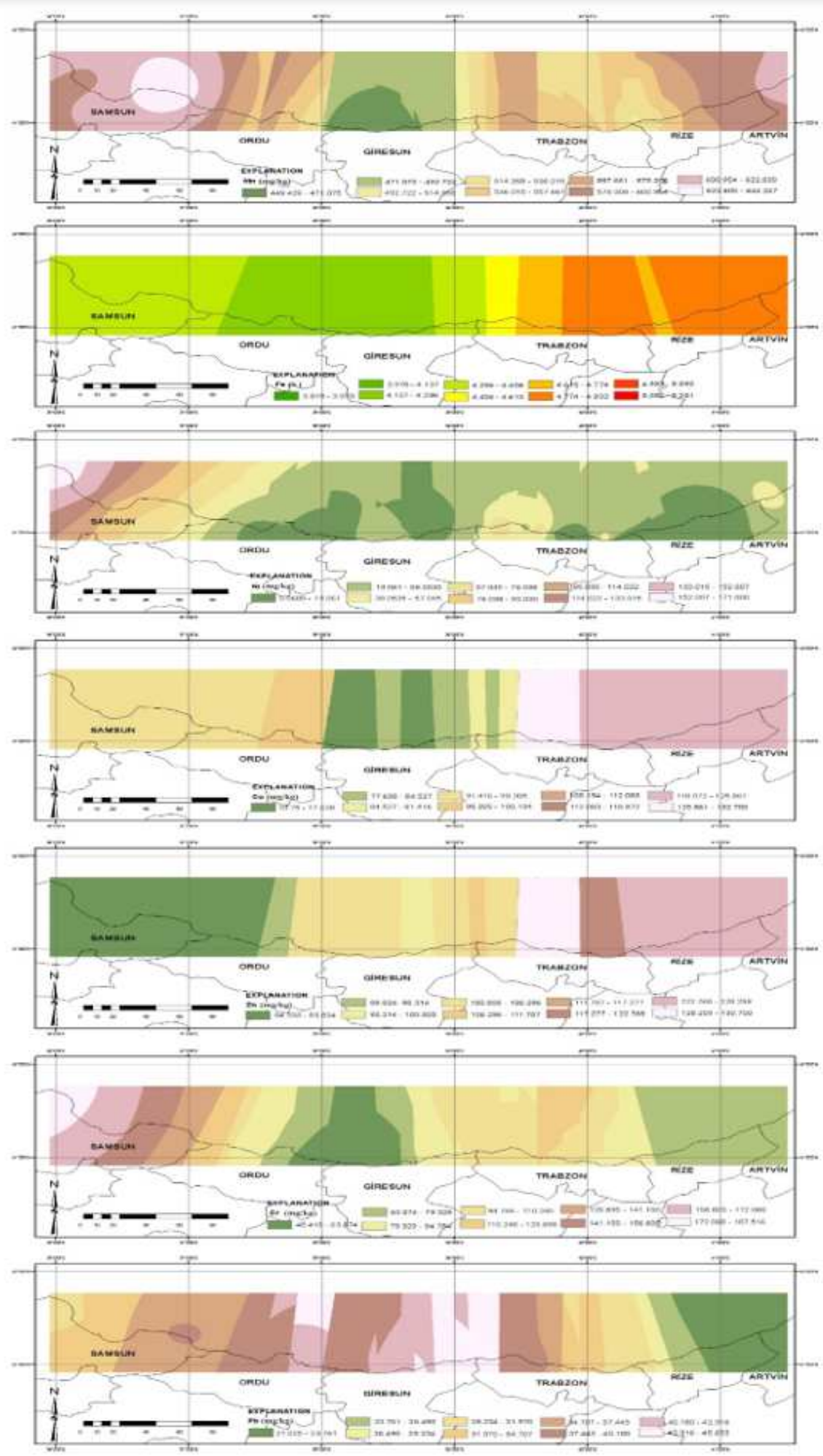

Figure 4

Spatial distribution of heavy metal contents. 